\title{
Low-weight polyethylenimine cross-linked
} 2-hydroxypopyl- $\beta$-cyclodextrin and folic acid as an efficient and nontoxic siRNA carrier for gene silencing and tumor inhibition by VEGF siRNA

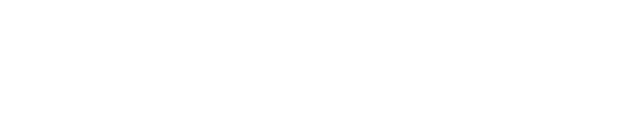

Jin-Ming Li

Yuan-Yuan Wang

Wei Zhang

Hua Su

Liang-Nian Ji

Zong-Wan Mao

MOE Key Laboratory of Bioinorganic and Synthetic Chemistry, School of Chemistry and Chemical Engineering, Sun Yat-sen University, Guangzhou, People's Republic of China
Correspondence: Zong-Wan Mao MOE Key Laboratory of Bioinorganic and Synthetic Chemistry, School of Chemistry and Chemical Engineering, Sun Yat-sen University, Guangzhou 510275, People's Republic of China

Tel +86 20 84II 3788

Fax +86 2084 II 2245

Email cesmzw@mail.sysu.edu.cn
Background: Targeted delivery of small interfering RNA (siRNA) has been regarded as one of the most important technologies for the development of siRNA therapeutics. However, the need for safe and efficient delivery systems is a barrier to further development of RNA interference therapeutics. In this work, a nontoxic and efficient siRNA carrier delivery system of low molecular weight polyethyleneimine (PEI-600 Da) cross-linked with 2-hydroxypopyl- $\beta$-cyclodextrin (HP- $\beta-C D)$ and folic acid (FA) was synthesized for biomedical application.

Methods: The siRNA carrier was prepared using a simple method and characterized by nuclear magnetic resonance and Fourier transform infrared spectroscopy. The siRNA carrier nanoparticles were characterized in terms of morphology, size and zeta potential, stability, efficiency of delivery, and gene silencing efficiency in vitro and in vivo.

Results: The siRNA carrier was synthesized successfully. It showed good siRNA binding capacity and ability to protect siRNA. Further, the toxicity of the carrier measured in vitro and in vivo appeared to be negligible, probably because of degradation of the low molecular weight PEI and HP- $\beta-C D$ in the cytosol. Flow cytometry and confocal microscopy confirmed that the FA receptor-mediated endocytosis of the FA-HP- $\beta$-CD-PEI/siRNA complexes was greater than that of the HP- $\beta-C D-P E I / s i R N A$ complexes in FA receptor-enriched HeLa cells. The FA-HP- $\beta$-CD-PEI/siRNA complexes also demonstrated excellent gene silencing efficiency in vitro (in the range of $90 \%$ ), and reduced vascular endothelial growth factor (VEGF) protein expression in the presence of $20 \%$ serum. FA-HP- $\beta$-CD-PEI/siRNA complexes administered via tail vein injection resulted in marked inhibition of tumor growth and reduced VEGF protein expression in the tumors.

Conclusion: Our results suggest that the FA-HP- $\beta$-CD-PEI complex is a nontoxic and highly efficient gene carrier with the potential to deliver siRNA for cancer gene therapy effectively in vitro and in vivo.

Keywords: polyethyleneimine, 2-hydroxypropyl- $\beta$-cyclodextrin, folic acid, siRNA carrier, vascular endothelial growth factor, gene silencing

\section{Introduction}

RNA interference utilizes small interfering RNA (siRNA) species that can downregulate the expression of specifically targeted genes. ${ }^{1}$ This technique has been regarded as a potentially powerful therapeutic agent for the treatment of various diseases, including cancer. ${ }^{2}$ However, like conventional gene therapy, a safe and efficient delivery system is still a barrier to further development of RNA interference therapeutics. ${ }^{3}$ Accordingly, recent siRNA delivery studies have emphasized the need for development 
of siRNA therapeutics, particularly for the treatment of cancer. ${ }^{4}$ Nucleic acid delivery methods can be classified into viral vector-mediated and nonviral vector-mediated. Viral vector-mediated delivery is very efficient and used in most clinical trials, especially for delivery of nucleic acids into the nucleus. However, the high potential for immunogenicity is a major drawback with viral vectors, and they are also difficult and expensive to produce. Further, viral vectors are most commonly used for delivery of short hairpin RNA rather than siRNA. Therefore, nonviral vectors has gradually become the mainstream for siRNA delivery. ${ }^{5}$

At present, many methods can be used to deliver siRNA in vitro and in vivo, including electroporation and microinjection. There are also other nonviral vector-mediated methods using polyethylene glycol-grafted polyethylenimine (PEI), peptides, low molecular weight chitosan, aptamer, serum albumin, and quantum dots..$^{6-11}$ The most widely used nonviral siRNA delivery systems are based on cationic lipids and cationic polymers. ${ }^{12}$ Cationic lipids can bind nucleic acid to form liposomes and achieve highly efficient gene silencing, as reported in the literature. ${ }^{13}$ However, liposomes show reduced transfection efficiency in vivo, and their application is limited by their high cytotoxicity. ${ }^{14}$ Cationic polymers, such as PEI, which was first used for gene delivery in $1995,{ }^{15}$ are used widely for siRNA delivery. PEI, with its high molecular weight of 25,000 Da, is regarded as one of the most efficient nonviral vehicles for gene silencing, ${ }^{16}$ but the strong positive surface charge on PEI causes severe cytotoxicity and nonspecific binding with serum proteins. ${ }^{14}$ On the other hand, low molecular weight PEI, such as PEI-600 Da, has very low cytotoxicity but shows poor transfection activity. ${ }^{17,18}$ To improve the poor transfection efficiency of low molecular weight PEI in gene delivery, some researchers have used low molecular weight PEI to cross-link with certain ligands, such as cyclodextrin. ${ }^{19}$ PEIcyclodextrin shows high gene transfection efficiency with very low cytotoxicity because cyclodextrins are a series of natural cyclic oligosaccharides with low immunogenicity and toxicity in animals and humans, especially in the form of 2-hydroxypopyl- $\beta$-cyclodextrin (HP- $\beta$-CD)..$^{20,21}$ Cyclodextrins can enhance biocompatibility, absorption, and resistance to nuclease enzymes by binding and interacting with oligonucleotides. ${ }^{22} \mathrm{HP}-\beta-\mathrm{CD}$ is approved by the US Food and Drug Administration for intravenous injection. Therefore, low molecular weight PEI cross-linked with HP- $\beta$-CD should be able to be used as an efficient siRNA delivery carrier with low cytotoxicity in vitro and in vivo. Such a compound had been used in pDNA delivery with good results. ${ }^{19,23}$ Tang et al used PEI-cyclodextrin as a novel multifunctional prodrug for codelivery of a conjugated chemotherapeutic agent, tegafur, and enhanced green fluorescent protein reporter plasmid DNA. ${ }^{24}$ Similarly, Pack et al found that cyclodextrin-PEI was less toxic to HEK293 cells than PEI. Further, addition of hydrophobic palmitate group (pal-HI) to cyclodextrinPEI enhanced gene expression by more than one order of magnitude compared with unmodified PEI with or without pal-HI. ${ }^{25}$ These reports indicate that cyclodextrin-PEI also has potential application in siRNA delivery.

Using low molecular weight PEI cross-linked with cyclodextrin can improve the gene transfection efficiency of an siRNA carrier, and with very low cytotoxicity. However, achieving higher transfection efficiency and targeted delivery in vivo requires a specific functional group to target the tumor, such as folic acid (FA), a peptide, or hyaluronic acid. ${ }^{26-28}$ The FA receptor appears to be present in most cancer cells, particularly in epithelial tumors, so is an ideal candidate for directing delivery of nanoparticles to target tumor cells. ${ }^{29}$

In this study, we used low molecular weight PEI crosslinked with HP- $\beta$-CD and FA to develop a gene carrier for delivery of siRNA. This carrier system showed high siRNA transfection efficiency in FA receptor-enriched HeLa cells, demonstrated low cytotoxicity, and helped target specific tumors in vivo for silencing of vascular endothelial growth factor (VEGF). The synthesized FA-HP- $\beta$-CD-PEI carrier was characterized by nuclear magnetic resonance and Fourier transform infrared spectroscopy, and found to be able to form a complex with VEGF siRNA and protect siRNA in serum. Further, 3-(4,5-dimethyl-thiazol-2-yl)-2,5-diphenyl tetrazolium bromide (MTT) assay showed that the FA-HP$\beta$-CD-PEI carrier had very low cytotoxicity both in vitro and in vivo. FA-HP- $\beta$-CD-PEI/siRNA nanoparticles also showed high cell transfection efficiency when compared with HP- $\beta-C D-P E I / s i R N A$ nanoparticles. Finally, we used this carrier to deliver VEGF siRNA and achieved effective gene silencing in vitro and in vivo for selectively targeted treatment of tumor tissue.

\section{Materials and methods Chemicals and reagents}

PEI (molecular weight $600 \mathrm{Da}, 25 \mathrm{kDa}$ ), 2-HP- $\beta-\mathrm{CD}$, FA, 1,1-carbonyldiimidazole (CDI), dicyclohexylcarbodiimide, N-hydroxysuccinimide, MTT, and Hoechst 33258 were obtained from Sigma-Aldrich (St Louis, MO, USA) and used without any additional purification. Four cell lines, ie, FA receptor-enriched HeLa, A549, HLF, and HepG2, were obtained from the Chinese Center for Type Culture 
Collections at Sun Yat-sen University. The cells were grown in $25 \mathrm{~cm}^{2}$ culture flasks (Corning Inc, Corning, NY, USA) at $37^{\circ} \mathrm{C}$ in a humidified atmosphere with $5 \% \mathrm{CO}_{2}$. The media used were Dulbecco's Modified Eagle Medium, 10\% fetal bovine serum, and $1 \%$ penicillin-streptomycin solution, all of which were sourced from HyClone Laboratories Inc (Logan, UT, USA). VEGF and $\beta$-actin monoclonal antibodies were obtained from Santa Cruz Biotechnology Inc (Santa Cruz, CA, USA). VEGF siRNA, including siRNA ${ }^{\mathrm{FAM}}$, was purchased from Dharmacon (La Fayette, CO, USA).

\section{Synthesis of FA-HP- $\beta-C D-P E I$}

HP- $\beta$-CD-PEI was synthesized in the manner described by Huang et al. ${ }^{30}$ First, $0.51 \mathrm{~g}(0.37 \mathrm{mmol})$ of HP- $\beta-C D$ was dissolved in $6 \mathrm{~mL}$ of dimethylsulfoxide with addition of $0.49 \mathrm{~g}$ ( $3 \mathrm{mmol}$ ) of cyclodextrin I (dissolved in $6 \mathrm{~mL}$ of dimethylsulfoxide). Next, $0.1 \mathrm{~mL}$ of triethylamine was added and the mixture was stirred for three hours in the dark at room temperature. The reaction system was protected by nitrogen. The hydroxyl group on 2-HP- $\beta$-CD was activated by cyclodextrin I and generated 2-HP- $\beta$-CD-CDI. This mixture was precipitated in cold ethylene, filtered, dissolved in $6 \mathrm{~mL}$ of

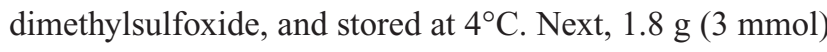
of PEI-600 Da was dissolved in $6 \mathrm{~mL}$ of dimethylsulfoxide. The previously prepared 2-HP- $\beta$-CD-CDI dissolved in $6 \mathrm{~mL}$ of dimethylsulfoxide and $0.1 \mathrm{~mL}$ of triethylamine was added dropwise over two hours with stirring for a further six hours in order to cross-link the hydroxyl group on the outside of $2-\mathrm{HP}-\beta-\mathrm{CD}$ with the amino groups of PEI. The mixture was dialyzed using a dialysis tube (molecular weight 2000) for two days in running water. The final solution was lyophilized for three days, and the end product, a white water-soluble solid, was deemed to be HP- $\beta$-CD-PEI.

Synthesis of FA-HP- $\beta$-CD-PEI was very similar, ie, $10 \mathrm{mg}(0.023 \mathrm{mmol})$ of FA was dissolved in $6 \mathrm{~mL}$ of dimethylsulfoxide with addition of $9.5 \mathrm{mg}(0.046 \mathrm{mmol})$ of dicyclohexylcarbodiimide. In another tube, $5.5 \mathrm{mg}$ ( $0.046 \mathrm{mmol})$ of dicyclohexylcarbodiimide was dissolved in $1.5 \mathrm{~mL}$ of dimethylsulfoxide. This solution was added to the FA solution, with $0.1 \mathrm{~mL}$ of triethylamine added to activate the FA. Next, $120 \mathrm{mg}$ of HP- $\beta$-CD-PEI was dissolved in $6 \mathrm{~mL}$ of dimethylsulfoxide, and the activated FA solution was added dropwise over two hours, with stirring for a further six hours to cross-link the carboxyl residues of the FA with the amino groups of PEI. This solution was then dialyzed using a dialysis tube (molecular weight 2000) for two days in running water. The final solution was lyophilized for three days, and the end product was deemed to be FA-HP- $\beta$-CD-PEI. Finally, the recovered conjugate was analyzed by ${ }^{1} \mathrm{H}$ nuclear magnetic resonance and Fourier transform infrared spectroscopy.

\section{Preparation and characterization of siRNA/FA-HP- $\beta$-CD-PEl complexes}

siRNA/FA-HP- $\beta$-CD-PEI complexes were prepared by mixing $2.5 \mu \mathrm{L}$ of siRNA $(100 \mathrm{nM})$ with FA-HP- $\beta$-CD-PEI solution followed by incubation at room temperature for 30 minutes. The nitrogen/phosphorus (N/P) ratio of FA-HP$\beta$-CD-PEI to siRNA varied from 0 to 24 , as measured by gel electrophoresis. The siRNA and siRNA/FA-HP- $\beta$-CD-PEI complexes were loaded into wells containing $1.5 \%$ agarose gel with ethidium bromide at a concentration of $0.1 \mathrm{mg} / \mathrm{mL}$. The gel was run for 20 minutes at $100 \mathrm{~V}$. The siRNA was visualized by bromide staining and a gel image was taken under ultraviolet-visible light. After dilution of the complex with $1 \mathrm{~mL}$ of water, the hydrodynamic volume and surface charge of the siRNA/FA-HP- $\beta$-CD-PEI complexes were measured using a zeta potential analyzer (Beckman Coulter Inc, Fullerton, CA, USA) in water. The size of the siRNA/ FA-HP- $\beta$-CD-PEI complexes were then measured by transmission electron microscopy (TEM, JEOL, Tokyo, Japan) and a zeta potential analyzer. To prepare a sample of the siRNA/FA-HP- $\beta$-CD-PEI complexes for TEM, we mixed $2.5 \mu \mathrm{L}$ of siRNA (100 nM) with FA-HP- $\beta$-CD-PEI solution followed by incubation at room temperature for 30 minutes; the same procedure was used to prepare a sample for the N/P ratio experiment, in which the N/P ratio was found to be 24 . A $5 \mu \mathrm{L}$ sample of the complex was dropped onto a copper net and observed by TEM at $100 \mathrm{kV}$ after dehydration.

\section{Protection of siRNA}

The naked siRNA and siRNA/FA-HP- $\beta$-CD-PEI complexes were incubated at $37^{\circ} \mathrm{C}$ for $0,1,3,6,12,24,48,72$, and 96 hours in the presence of $50 \%$ calf serum. At these time points, aliquots were taken from the solutions and placed directly into gel loading buffer containing $1 \%$ sodium dodecyl sulfate and kept chilled at $4{ }^{\circ} \mathrm{C}$. After incubation of the siRNA/ FA-HP- $\beta$-CD-PEI complexes with serum, $1 \%$ sodium dodecyl sulfate was used to dissociate the siRNA from its carrier before gel electrophoresis in order to quantify the amount of intact siRNA. Finally, siRNA was run on $1.5 \%$ agarose gel followed by visualization using ethidium bromide staining.

\section{Cell cytotoxicity testing}

The cytotoxicity of FA-HP- $\beta$-CD was evaluated by MTT assay. The cells were collected by trypsinization, counted, 
and plated in 96-well flat-bottomed microtiter plates (Corning Inc) at a density of 5000 cells per well, with $100 \mu \mathrm{L}$ of cell suspension medium per well. For the chemosensitivity assays, the carriers were tested at concentrations of $0,10,25,50,100$, $150,200,300$, and $500 \mu \mathrm{g} / \mathrm{mL}$, respectively, ( 0 concentration of carrier meaning that no carrier was added to the cells, ie, controls). The optimal concentration of carrier used in the experiment was considered in order to achieve optimal transfection results with minimal cellular cytotoxicity (balanced silencing efficiency and cellular cytotoxicity). For the cytotoxicity studies, the transfection reagents were diluted in Dulbecco's modified Eagle's medium and incubated with cells for 48 hours. The cells were then incubated with $20 \mu \mathrm{L}$ of MTT for 4 hours at $37^{\circ} \mathrm{C}$ and washed subsequently with $100 \mu \mathrm{L}$ of $1 \times$ phosphate-buffered saline (PBS) three times. After the cell analysis, the intracellular formazan product was dissolved in $100 \mu \mathrm{L}$ of dimethylsulfoxide and quantified using an Infinite F200 device (Tecan Inc, Männedorf, Switzerland) at a wave length of $595 \mathrm{~nm}$. The relative cell growth $(\%)$ for the controls (containing cell culture medium) was calculated as: test/control $\times 100$.

\section{Intracellular delivery of siRNA ${ }^{\text {FAM/ }}$ FA-HP- $\beta$-CD-PEl complexes}

The cellular uptake of siRNA ${ }^{\text {FAM }} / F A-H P-\beta-C D-P E I$ complexes was investigated by fluorescence microscopy and flow cytometry. For imaging by fluorescence microscopy, HeLa cells were seeded in a $35 \mathrm{~mm}^{2}$ Petri dish from Mattek Co (Ashland, MA, USA) at a density of $10^{5}$ cells and maintained for 24 hours. The siRNA ${ }^{\text {FAM }} / F A-H P-\beta-C D-P E I$ complexes were prepared at a ratio of 1:24 (the concentration of siRNA ${ }^{\text {FAM }}$ was $100 \mathrm{~nm}$ ) in serum-free medium and incubated at room temperature for 20 minutes. The medium containing serum was added to the solution, followed by cell transfection with the complexes and two hours of incubation. After transfection, the medium was discarded and the cells were washed three times with PBS, stained with Hoechst 33342 solution, and washed again in PBS. Images were obtained using a Leica TCS SP5 confocal laser scanning microscope (Leica Inc, Allentown, NJ, USA). For flow cytometry, HeLa cells were seeded on 12-well plates at a density of $10^{5}$ cells/well and were incubated for 24 hours. The culture medium was exchanged for medium containing siRNA $^{\text {FAM/FA-HP- } \beta \text {-CD-PEI complexes at an siRNA }}{ }^{\text {FAM }}$ concentration of $100 \mathrm{~nm}$. After incubation for four hours, the cells were detached with trypsin and washed three times with PBS. The cells were fixed with 1\% paraformaldehyde and analyzed using flow cytometry (BD FACSCalibur ${ }^{\mathrm{TM}}, \mathrm{BD}$ Bioscience, San Jose, CA, USA).

\section{Gene silencing of siVEGF/FA-HP- $\beta$-CD- PEI complexes on Western blotting}

After transfection, the cells and nontransfected controls were lysed using M-PER ${ }^{\circledR}$ protein extraction reagent (Pierce Inc, Rockford, IL, USA). The lysates were separated by centrifugation at $12,000 \mathrm{rpm}$ and $4^{\circ} \mathrm{C}$ for 10 minutes on an Eppendorf 5417R centrifuge (Eppendorf Inc, Hamburg, Germany). The supernatants were collected and the protein concentration was measured using a standard bicinchoninic acid protein assay kit (Novagen Inc, Madison, WI, USA). Equal amounts of protein were loaded and separated by $12 \%$ sodium dodecyl sulfate polyacrylamide gel electrophoresis. The proteins were then transferred from the gel onto nitrocellulose membranes (BioRad Inc, Hercules, CA, USA) in transfer buffer ( $25 \mathrm{mM}$ Tris $\mathrm{HCl}$, $200 \mathrm{mM}$ glycine, 10\% methanol) using a Mini-PROTEAN4 device (BioRad Inc) over one hour at $150 \mathrm{~V}$. The membranes were blocked with 5\% milk blocking buffer for two hours on a horizontal shaker. The blocked membranes were incubated with 1:1000 VEGF mouse monoclonal antibody (Santa Cruz Inc) diluted in 5\% milk blocking buffer overnight. The membranes were washed in Tween-tris buffered saline consisting of $0.1 \%$ Tween-20 in $100 \mathrm{mM}$ Tris HCL (pH 7.5) and 0.9\% NaCl. The membranes were probed with mouse antirabbit secondary antibody (Santa Cruz Inc) labeled with horseradish peroxidase and diluted to 1:5000 in 5\% milk blocking buffer. The blots were developed using an ECL kit (Amersham Pharmacia Biotech, Piscataway, NJ, USA). The membranes were exposed to Kodak X-OMAT film for 10-30 seconds for data acquisition and developed using a conventional developing device.

\section{In vivo cytotoxicity assays of the FA-HP- $\beta-C D-P E I$ carrier}

All animal experiments were conducted in accordance with the guidelines of the local animal welfare committee and were carried out in compliance with the animal protection regulations in People's Republic of China. A tail vein injection assay was performed to test the cytotoxicity of the FA-HP- $\beta$-CD-PEI carrier in vivo. Female nude mice aged 6-7 weeks were divided into four groups ( $\mathrm{n}=4$ per group). Group A included control mice injected with PBS, and Groups B, C, and D were injected with the FA-HP- $\beta$-CD-PEI carrier at doses of 100, 200, and $300 \mathrm{mg} / \mathrm{kg}$, respectively. After injection, we observed the condition of the animals in the each group (alive or dead).

\section{In vivo tumor treatment using siVEGF/FA-HP- $\beta$-CD-PEl complexes}

To generate tumors, $100 \mu \mathrm{L}$ of HeLa suspension in PBS $\left(10^{6}\right.$ cells) was subcutaneously injected into the mid right 
flank of each nude mouse. Tumor size was measured using a vernier caliper across the longest (a) and shortest (b) diameters, and tumor volume was calculated using the formula: $\mathrm{V}=0.5 \mathrm{a} \times \mathrm{b}^{2}$. Eight to ten days later, when the tumor growth had reached a size of approximately $80 \mathrm{~mm}^{3}$, the tumors were treated with $100 \mu \mathrm{L}$ of the four study compounds, ie, PBS only (control), or PBS containing nonspecific siRNA of siLuc/FA-HP- $\beta$-CD-PEI complexes, siVEGF/HP- $\beta$-CDPEI complexes, or siVEGF/FA-HP- $\beta$-CD-PEI complexes. Each of these compounds was injected via the tail vein. The injections were administered three times and injected again three days after the last injection (final volume of $100 \mu \mathrm{L}$, $5 \mathrm{mg}$ siRNA per mouse). The treated mice were examined for appearance, necrosis, and physical activity. The tumor volume was measured every three days. Three mice from each group were sacrificed one day after the last injection of the siRNA complexes. The tumors were excised and homogenized for protein extraction. After approximately 20 days, VEGF protein expression in the tumor tissue was analyzed by Western blotting.

\section{Statistical analysis}

Statistical analysis of the data was performed by one-way analysis of variance using Statistical Package for Social Sciences software version 13.0 (SPSS Inc, Chicago, IL, USA). The results are expressed as the mean \pm standard deviation and $P<0.05$ was considered to be statistically significant. All the statistical analyses were two-sided.

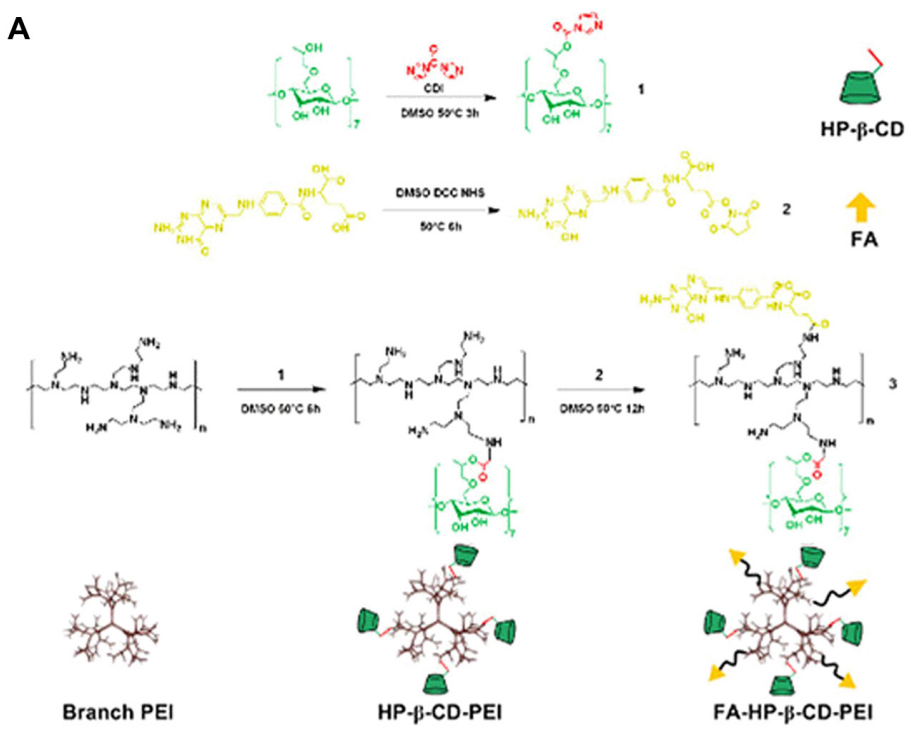

B

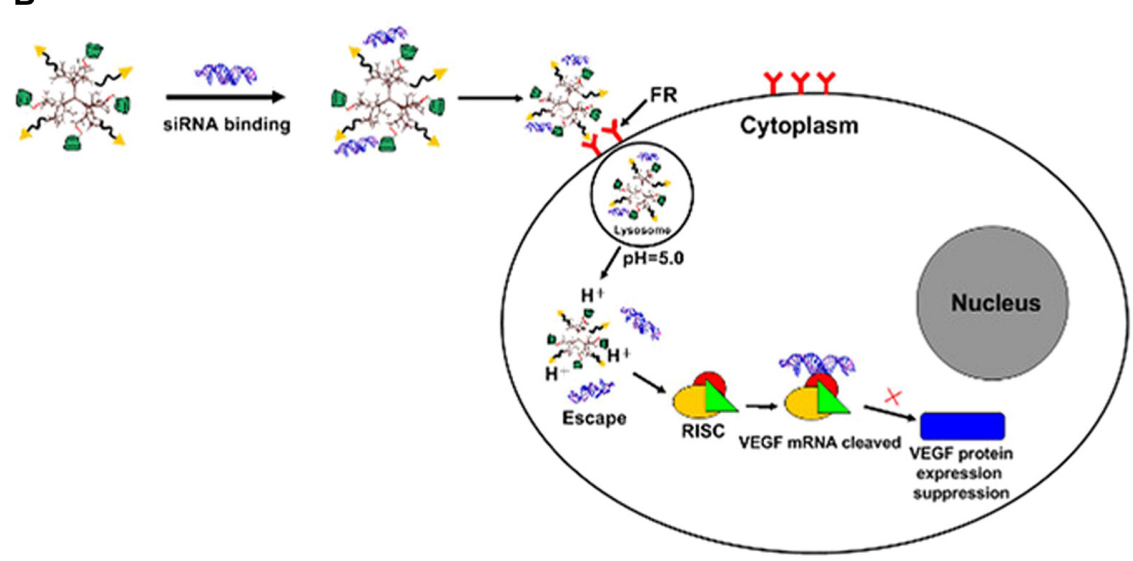

Figure I The synthesize process of the FA-HP- $\beta$-CD-PEI carrier $(\mathbf{A})$ and the siRNA/FA-HP- $\beta$-CD-PEl nanoparticle formation by electrostatic interactions, the nanoparticle adsorbed with cancer cells surface by FR and finally the siRNA release from the lysosome by the low $\mathrm{pH}$ condition (B).

Note: The nanoparticles were adsorbed onto the surface of the cancer cell by the FA receptor, with release of siRNA from the lysosome at low $\mathrm{pH}$.

Abbreviations: FA, folic acid; FR, folate receptor; HP- $\beta-C D$, 2-hydroxypopyl- $\beta$-cyclodextrin; PEI, polyethyleneimine; siRNA, small interfering RNA; VEGF, vascular endothelial growth factor. 


\section{Results and discussion}

\section{Synthesis and characterization}

\section{of the FA-HP- $\beta$-CD-PEI carrier}

FA-HP- $\beta$-CD-PEI complexes were successfully developed as a carrier for target-specific siRNA, and the synthesis procedure is shown in Figure 1. To enhance gene transfection efficiency and reduce cytotoxicity, a low molecular weight branch PEI of 600 Da was cross-linked with HP- $\beta-C D$, the product of which (HP- $\beta$-CD-PEI) was coupled with FA for targeting VEGF-siRNA to tumor tissue.

The HP- $\beta$-CD-PEI was synthesized by cyclodextrin I, which cross-linked the HP- $\beta$-CD and PEI. ${ }^{30}$ Next, FA was activated and coupled with HP- $\beta-C D-C D I$. This activated the carboxyl group of FA, which then enabled coupling with PEI via acidic amides. As a result, the carboxyl group in FA was cross-linked with the amino groups of PEI. The reaction mixture was dialyzed using a dialysis tube (molecular weight 12,000) for two days in running water, and the final solution was lyophilized for three days to remove the nonreacted FA and HP- $\beta$-CD-PEI. Finally, we achieved a pale water-soluble solid (FA-HP- $\beta$-CD-PEI, Figure 1A) which was able to deliver siRNA to the FA receptor-enriched cells and release siRNA at a low $\mathrm{pH}$ (Figure 1B). The recovered conjugate was analyzed by ${ }^{1} \mathrm{H}$ nuclear magnetic resonance (Figure $\mathrm{S} 1$ ) and Fourier transform infrared spectroscopy (Figure S2).

Successful conjugation of FA onto the backbone of PEI-600-HP- $\beta$-CD was confirmed by ${ }^{1} \mathrm{H}$ nuclear magnetic resonance (Figure $\mathrm{S} 1$ ), which showed that the signals from PEI ethylene protons (- $\left.\mathrm{CH}_{2}-\mathrm{CH}_{2}-\mathrm{NH}-\right)$ appeared at 2.4-3.0 ppm and that the $\mathrm{H}_{1}$ proton and $\mathrm{H}_{2}-\mathrm{H}_{6}$ protons of $\mathrm{HP}-\beta-\mathrm{CD}$ appeared at $5.0 \mathrm{ppm}$ and $3.0-4.0 \mathrm{ppm}$, respectively. Only three small peaks corresponding to the aromatic protons (6.5-8.5 ppm) were observed in the $\mathrm{H}^{1}$ nuclear magnetic resonance spectrum, indicating successful conjugation of the folate moiety to PEI-600-HP- $\beta$-CD.

Fourier transform infrared spectroscopy showed a yellow water-soluble solid product, FA-HP- $\beta$-CD-PEI, which had the characteristic - CO-NH- peaks of 1607, 1509, and 1407 (Figure S2). This was different from the carboxyl group in FA (characteristic peak 1693) and the amino group in HP- $\beta-C D-$ PEI (characteristic peaks 1550, 1464, 1369, and 1270). This also demonstrated that the FA and HP- $\beta$-CD-PEI were linked. Ultraviolet-visible spectrophotometry (Figure S3) and thermogravimetry (Figure $\mathrm{S} 4$ ) also demonstrated the formation of FA-HP- $\beta$-CD-PEI. The characteristics of HP- $\beta$-CD-PEI and FA-HP- $\beta$-CD-PEI are shown in Table S1, including molecular weight, size, and electric charge on the carriers. ${ }^{1} \mathrm{H}$ nuclear magnetic resonance and Fourier transform infrared spectroscopy findings for HP- $\beta$-CD-PEI are shown in Figures S5 and S6.

\section{Preparation and characterization of siRNA/FA-HP- $\beta$-CD-PEl complexes}

The siRNA/FA-HP- $\beta$-CD-PEI complexes were formed by mixing $2.5 \mu \mathrm{L}$ of siRNA (100 nM) with FA-HP- $\beta$-CD-PEI solution followed by incubation for 30 minutes at room temperature. The N/P ratio of FA-HP- $\beta$-CD-PEI to siRNA varied from 0 to 24 , as measured by gel electrophoresis (Figure $2 \mathrm{~A}$ ). When the N/P ratio of FA-HP- $\beta$-CD-PEI to siRNA was $24: 1$, the siRNA was blocked completely, indicating that an N/P ratio of 24 for this nanoparticle was the best, and this ratio was used in all the following experiments.
A

$\begin{array}{lllllll}M & 0 & 1.2 & 2.4 & 6 & 12 & 24\end{array}$

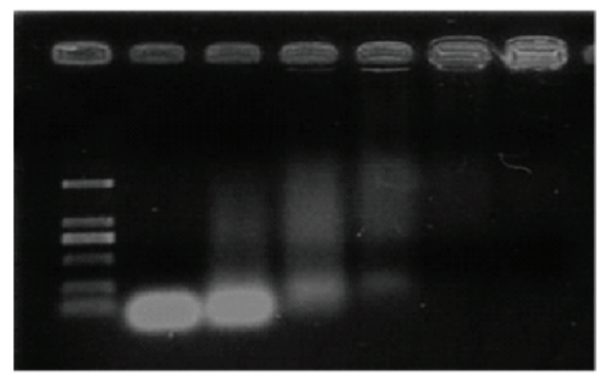

FA-HP- $\beta$-CD-PEI: siRNA N/P ratio
B

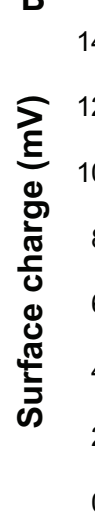

$+13.5 \mathrm{mV}$

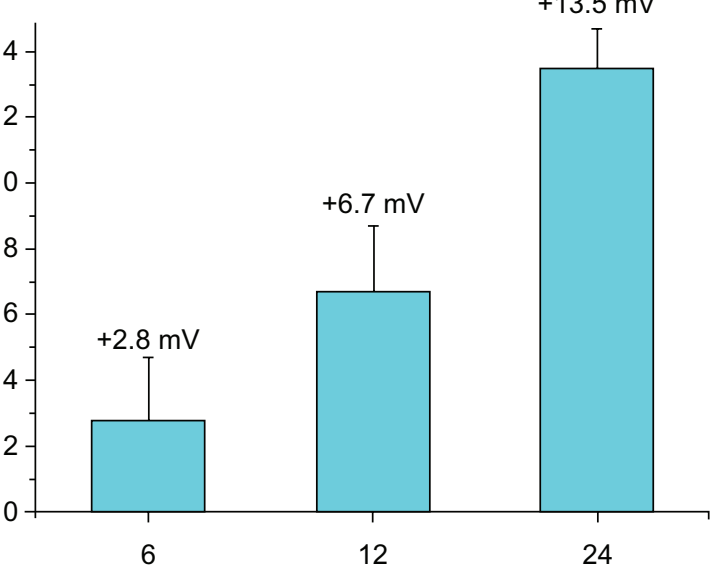

FA-HP- $\beta$-CD-PEI: siRNA N/P ratio

Figure 2 Characterization of FA-HP- $\beta$-CD-PEI-600/siRNA complex. (A) The agarose gel electrophoresis of FA-HP- $\beta$-CD-PEI-600/siRNA complex with different N/P ratios $(0,1.2,2.4,6, I 2$ and 24). (B) The surface charge characteristics of FA-HP- $\beta-C D-P E I-600 / s i R N A$ complex with different N/P ratios (6, I2 and 24).

Abbreviations: FA, folic acid; HP- $\beta$-CD, 2-hydroxypopyl- $\beta$-cyclodextrin; NP, nitrogen/phosphorus; PEl, polyethyleneimine; siRNA, small interfering RNA. 
Based on the results of gel electrophoresis, different N/P ratios for the complexes $(6,12$, and 24$)$ were studied using the zeta potential analyzer (Figure 2B), and it was found that an N/P ratio of 24 gave a good positive charge $(+13.5 \mathrm{mV})$ for performing further experiments in vitro and in vivo. This can be explained by the fact that too high a positive charge on the complex causes cationic cytotoxicity. Further, in vivo, too high a cationic charge could enhance binding to cellular components in the blood, eg, erythrocytes, and/or nonspecific binding to serum proteins as well as endothelium in vessel walls.

The size of the nanoparticle is a crucial factor in determining the rate of cellular uptake of nucleic acid polyplexes. ${ }^{31}$ A TEM image of the siRNA/FA-HP- $\beta$-CD-PEI complex at a ratio of 24 is shown in Figure 3, indicating that the size of the siRNA/FA-HP- $\beta$-CD-PEI complex was about $250 \mathrm{~nm}$ with a compact structure and characteristic globular morphology. The positive charge on the carrier being offset by the negative charge on the siRNA may be the reason why the complex has such a uniform size distribution.

\section{Protection of siRNA}

SiRNA is easily degraded by nuclease, which has prevented use of siRNA in RNA interference therapy and underscores the need for a carrier to be able to protect siRNA. Therefore, an siRNA protection experiment was performed to assess the ability of the FA-HP- $\beta$-CD-PEI carrier to protect siRNA. The results showed that the FA-HP- $\beta$-CD-PEI carrier protected the siRNA effectively at $37^{\circ} \mathrm{C}$ and for 96 hours in the presence of $50 \%$ calf serum (Figure 4 ). When naked, the siRNA

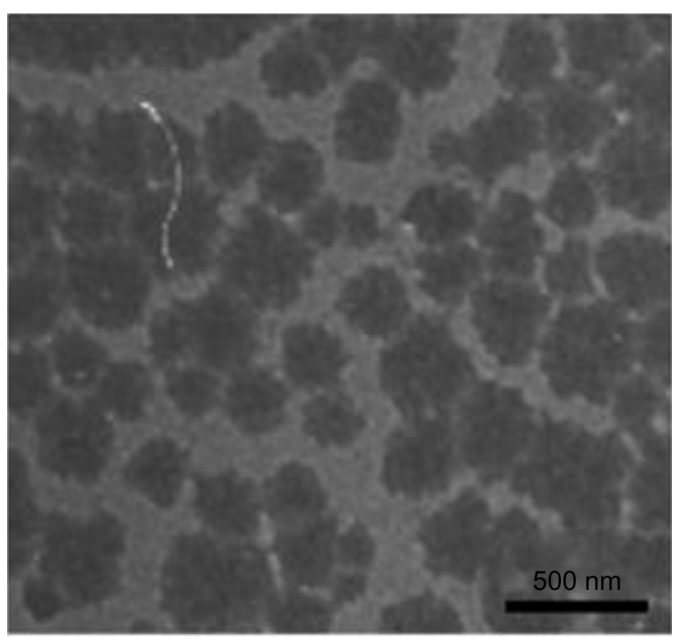

FA-HP- $\beta$-CD-PEI-600/siRNA

Figure 3 The representative transmission electron microscope (TEM) image of the siRNA/FA-HP- $\beta-C D-P E I$ complex. The FA-HP- $\beta-C D-P E I / s i R N A$ complex was uniform in distribution and had a compact structure.

Abbreviations: FA, folic acid; HP- $\beta-C D$, 2-hydroxypopyl- $\beta$-cyclodextrin; PEI, polyethyleneimine; siRNA, small interfering RNA; N/P, nitrogen/phosphorus.

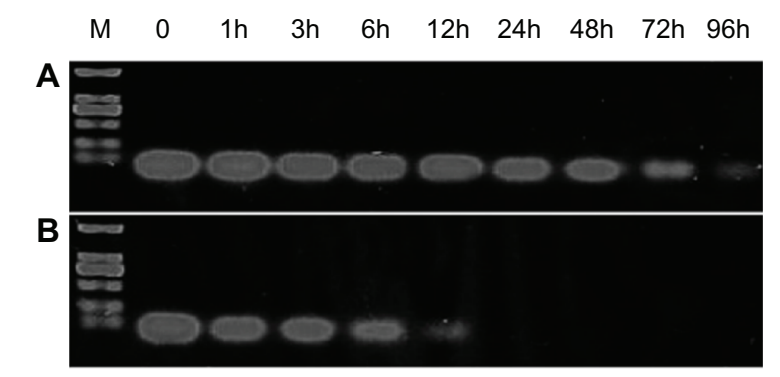

Figure 4 The siRNA protection efficiency of FA-HP- $\beta-C D-P E I$. siRNA protected by FA-HP- $\beta$-CD-PEI (A) and the naked siRNA (B) were incubated for 0, I, 3, 6, I2, 24 , 48,72 and $96 \mathrm{~h}$ at $37^{\circ} \mathrm{C}$ in the presence of $50 \%$ calf serum.

Notes: After incubation, the products were run on $1.5 \%$ agarose gel followed by visualization using ethidium bromide staining. Before being run on the gel, the siRNA/FA-HP-B-CD-PEI complexes were treated with sodium dodecyl sulfate to release siRNA from the carrier. The amount of siRNA remaining was measured by photometric density.

Abbreviations: FA, folic acid; h, hours; HP- $\beta-C D$, 2-hydroxypopyl- $\beta$-cyclodextrin; PEI, polyethyleneimine; siRNA, small interfering RNA; M, marker (DL 2000).

was almost entirely degraded after incubation with 50\% calf serum at $37^{\circ} \mathrm{C}$ for 12 hours, whereas more than $90 \%$ of the siRNA was conserved when protected by the carrier. Likewise, the gel results confirmed that more than $80 \%$ of the siRNA remained, indicating that more than $60 \%$ of the siRNA was protected. However, when incubation was continued for longer than 96 hours, less siRNA remained. Overall, the gel results confirmed that the FA-HP- $\beta$-CD-PEI carrier could protect siRNA from enzymatic degradation, so we proceeded to in vivo experiments.

\section{Cytotoxicity assay}

The MTT assay was used to evaluate the cytotoxicity of the HP- $\beta$-CD-PEI and FA-HP- $\beta$-CD-PEI complexes in vitro in the different tumor cell lines. Figure $5 \mathrm{~A}-\mathrm{D}$ shows the viability of HeLa, HLF, A549 and HepG2 cells incubated with various concentrations of PEI-25 kDa, PEI-600 Da, HP- $\beta$-CD-PEI, and FA-HP- $\beta$-CD-PEI. PEI-25 kDa showed high transfection efficiency but also had high cytotoxicity in vitro and in vivo. The MTT assay also showed that PEI-25 kDa was more cytotoxic than PEI-600 Da, HP- $\beta$-CD-PEI, or FA-HP- $\beta$-CDPEI. Moreover, at all concentrations tested, the viability of cells incubated with HP- $\beta$-CD-PEI and FA-HP- $\beta-C D-P E I$ was similar to that of cells incubated with PEI-600 Da. The conclusion was that none of these three substances were cytotoxic in any of the cell lines.

Likewise, viability was about $90 \%$ in all cell lines treated with PEI-600 Da, HP- $\beta$-CD-PEI, and FA-HP- $\beta$-CD-PEI, on exposure to $300 \mu \mathrm{g} / \mathrm{mL}$ of the substance. In fact, viability of the cell cultures treated with HP- $\beta-C D-P E I$ and FA-HP- $\beta-C D-$ PEI was more than $90 \%$, while that of the cell culture treated with PEI-600 Da decreased to about $80 \%$ at a concentration 

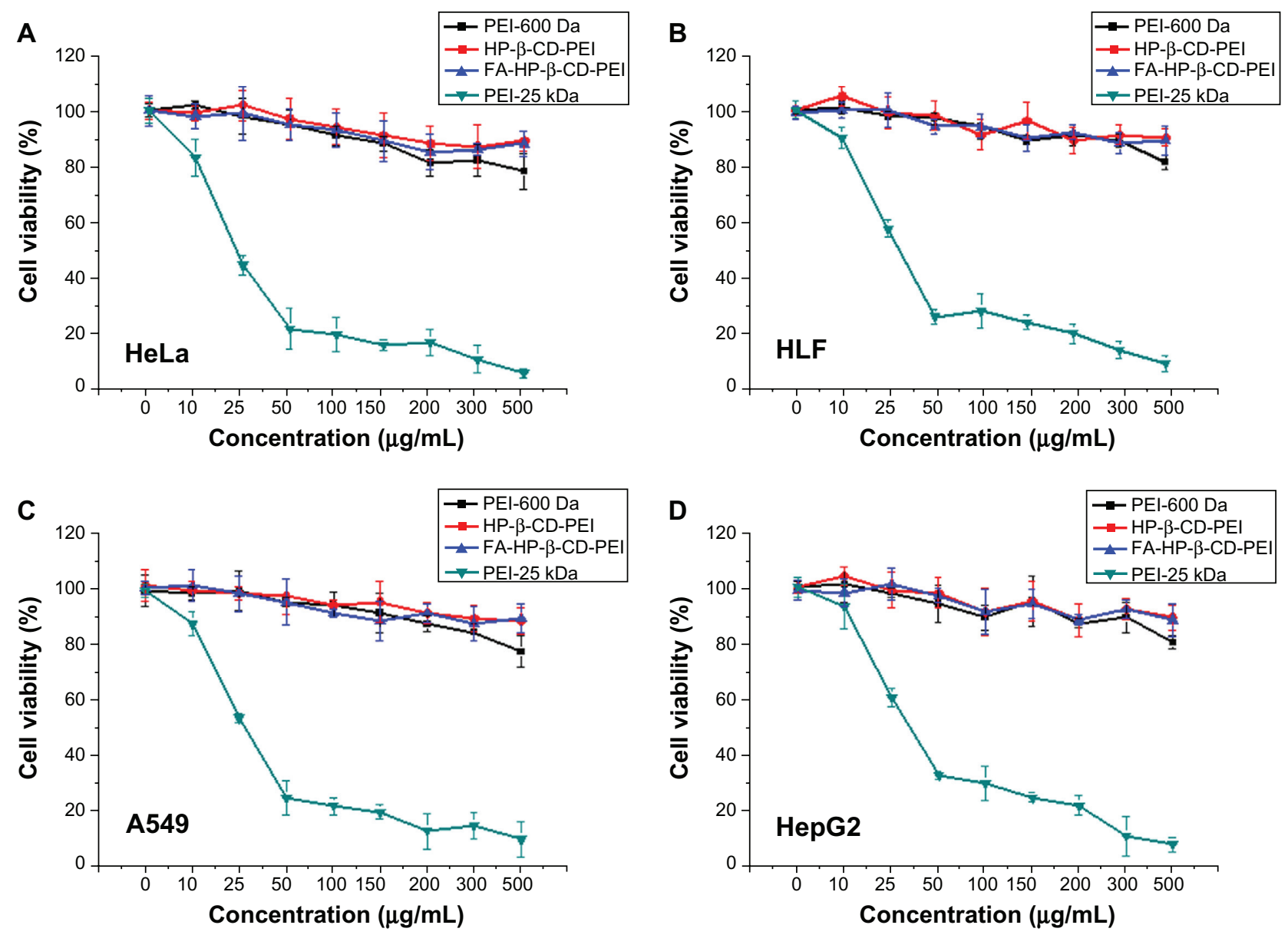

Figure 5 The cytotoxicity of HP- $\beta-C D-P E l$ and FA-HP- $\beta-C D-P E l$ in different tumor cell lines. Panels A, B, C and D show the cell viability of HeLa, HLF, A549 and HepG2 cells incubated with various concentrations of PEI-25 kDa, PEI-600 Da, HP- $\beta$-CD-PEl and FA-HP- $\beta$-CD-PEl; respectively.

Note: Concentrations of the polymer were $0-500 \mathrm{mg} / \mathrm{mL}$.

Abbreviations: FA, folic acid; HP- $\beta-C D$, 2-hydroxypopyl- $\beta$-cyclodextrin; PEI, polyethyleneimine.

of $500 \mu \mathrm{g} / \mathrm{mL}$. This result indicates that cross-linking of HP- $\beta$-CD could reduce the cytotoxicity of the carrier because HP- $\beta-C D$ has no toxicity (as certified by the US Food and Drug Administration) and could reduce some of the positive charge on PEI, which causes cationic toxicity in cells.

In the next step, we performed a toxicity experiment in vivo to measure the $\mathrm{LD}_{50}$ of the FA-HP- $\beta$-CD-PEI carrier. The concentration of the FA-HP- $\beta$-CD-PEI carrier used to inject the nude mice was in the range of $100-300 \mathrm{mg} / \mathrm{kg}$ $(100 \mathrm{mg} / \mathrm{kg}, 200 \mathrm{mg} / \mathrm{kg}$, and $300 \mathrm{mg} / \mathrm{kg}$, respectively). The condition of the injected mice was observed for 24 hours after each injection, and it was found that the FA-HP- $\beta$-CDPEI carrier had no serious toxicity at the concentrations used. However, the condition of the mice deteriorated when the concentration of the carrier was $300 \mathrm{mg} / \mathrm{kg}$. It has been reported that the $\mathrm{LD}_{50}$ of linear PEI-25 $\mathrm{kDa}$ is around $4 \mathrm{mg} / \mathrm{kg}$ in mice, ${ }^{32}$ which significantly limits its use in vivo. In comparison, cyclodextrin polymers are less toxic, with an $\mathrm{LD}_{50}$ of about $200 \mathrm{mg} / \mathrm{kg}$ in mice. ${ }^{33}$ The toxicity assay for the
FA-HP- $\beta$-CD-PEI carrier showed no serious toxicity in vivo. This could be explained by the limited cytotoxicity of low molecular weight PEI and HP- $\beta-C D$, making this carrier a promising agent for in vivo gene delivery. Several recent studies have demonstrated that HP- $\beta-C D$ can significantly disrupt lipid rafts and influence electroporation-induced or potassium currents. However, these reports are based on the use of a large amount of HP- $\beta-C D$, whereas the amount of HP- $\beta$-CD used as a siRNA carrier in our study was very low, and would not have disrupt lipid rafts or influence electroporation-induced or potassium currents to a significant extent. Our cytotoxicity testing in vivo did not reveal any serious immunological reactions in the nude mouse.

\section{Intracellular uptake efficiency of siRNA/ FA-HP- $\beta$-CD-PEI complexes}

The efficiency of delivery of siRNA ${ }^{\mathrm{FAM}} / \mathrm{FA}-\mathrm{HP}-\beta-\mathrm{CD}-\mathrm{PEI}$ complexes into FA receptor-enriched HeLa cells was investigated by fluorescence microscopy and flow cytometry. 


\section{A}
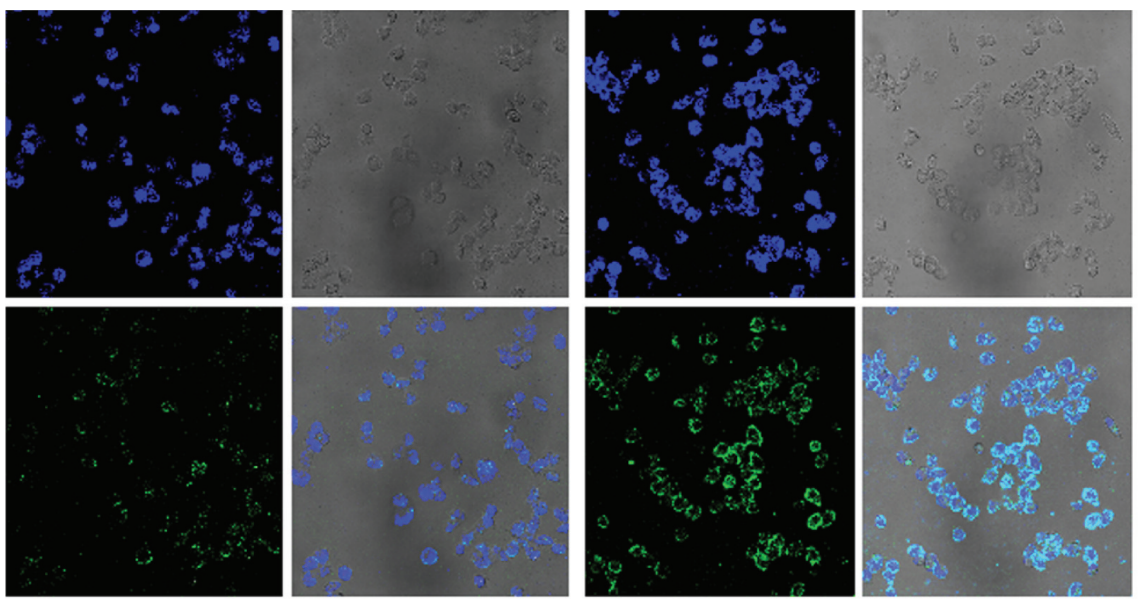

HP- $\beta$-CD-PEI/siRNA complex

FA-HP- $\beta$-CD-PEI/siRNA complex

B
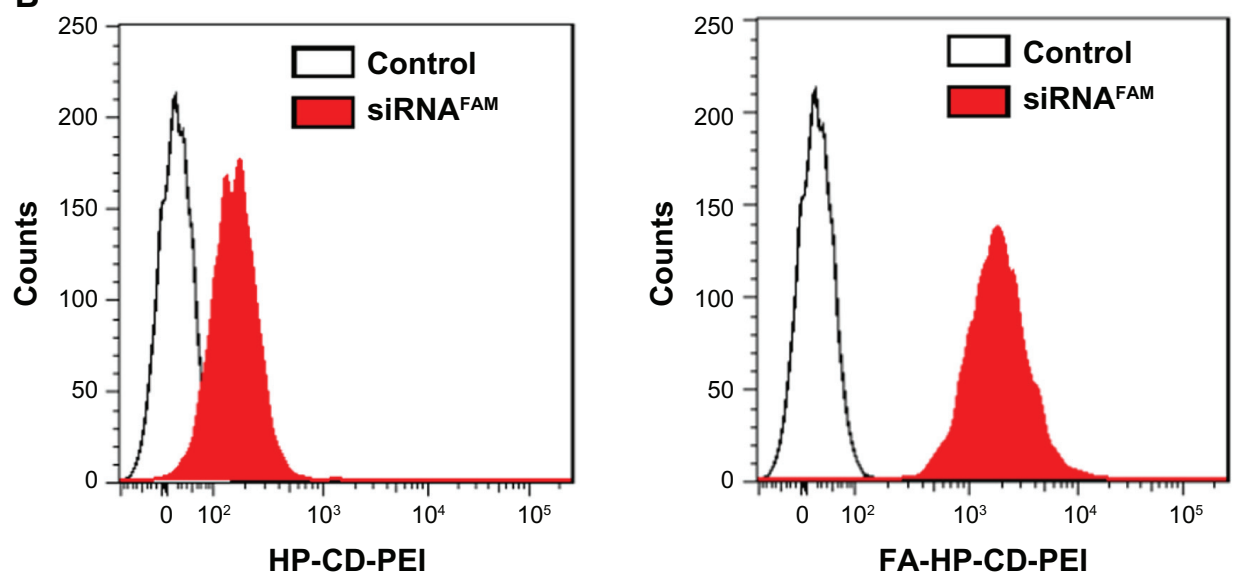

Figure 6 The fluorescence microscopy images (A) and the flow cytometric analyses (B) displayed the intracellular uptake of the HP- $\beta$-CD-PEl/siRNAFAM and FA-HP- $\beta$ CD-PEI/siRNA FAM complexes in FR-riched HeLa cells.

Notes: The incubation time was four hours, the dose of siRNA was $100 \mathrm{nM}$, and the NP ratio of carrier:siRNA was 24 . Nuclei were stained blue with Hoechst 33342 and green fluorescence revealed siRNA ${ }^{\text {FAM }}$.

Abbreviations: FA, folic acid; HP- $\beta-C D$, 2-hydroxypopyl- $\beta$-cyclodextrin; PEl, polyethyleneimine; siRNA, small interfering RNA.

FAM-labeled scrambled siRNA was used to visualize the cellular uptake of siRNA. On confocal microscopy (Figure 6A), the siRNA ${ }^{\text {FAM }} / \mathrm{FA}-\mathrm{HP}-\beta-\mathrm{CD}-\mathrm{PEI}$ complexes were taken up into HeLa cells more efficiently than the siRNA ${ }^{\text {FAM/ }}$ HP- $\beta$-CD-PEI complexes after four hours of incubation. This could be due to receptor-mediated endocytosis of the FA-HP- $\beta-C D-P E I$ carrier in HeLa cells bearing the FA receptor. Nanocarrier theory favors easy entry of nanoparticles by endocytosis. This theory is based on the attachment of a ligand to a nanoparticle that commonly leads to selectively targeted cell delivery and cell internalization via a mechanism known as receptor-mediated endocytosis, especially with ligand delivery receptors, such as the FA receptor. ${ }^{34}$ The FA receptor is present in most tumors, including those of the breast, brain, colon, endometrium, lungs, ovaries, and myeloid cells of hematopoietic origin. ${ }^{35}$ Therefore, the FA receptor is an interesting functional group for selective targeting of cancer cell.
Flow cytometry analysis of transfection efficiency showed that intracellular uptake of the siRNA/FA-HP- $\beta$-CD-PEI complexes was superior to that of the siRNA/HP- $\beta$-CD-PEI complexes (see Figure 6B). After four hours of incubation, cells incubated with the siRNA/FA-HP- $\beta$-CD-PEI complexes showed much stronger siRNA (red) fluorescence in comparison with cells incubated with the nontargeting siRNA/HP-ß-CD-PEI complexes. Quantitative flow cytometry showed that the fluorescence intensity of positive cells increased by about four-fold when incubated with siRNA/ FA-HP- $\beta$-CD-PEI in comparison with those incubated with siRNA/HP-ß-CD-PEI (807 versus 192, respectively). These results indicate the siRNA was transferred into the cells much more efficiently using targeting rather than nontargeting nanocomplexes. Considering all these results, FA coupled to an HP- $\beta$-CD-PEI carrier for delivery of siRNA contributed significantly to the improved cellular uptake via FA receptormediated endocytosis. This shows that it is possible to target 
tissues with the FA receptor for specific gene delivery in the treatment of cancer.

\section{Gene silencing efficiency of siRNA/ FA-HP- $\beta$-CD-PEI complexes}

The gene silencing efficiency of the siRNA/FA-HP- $\beta-C D-$ PEI complexes was investigated by Western blotting, using commercial transfection reagents [SiPORT ${ }^{\mathrm{TM}}$ NeoFX ${ }^{\mathrm{TM}}$ (Invitrogen, Carlsbad, CA, USA) and HiPerFect ${ }^{\circledR}$ (Qiagen, Valencia, CA, USA)] for comparison. siRNA was used to silence the $V E G F$ gene in HeLa cells. SiRNA/FA-HP- $\beta-C D-$ PEI and siRNA/HP- $\beta$-CD-PEI complexes were prepared by mixing the carrier with siRNA in siRNA buffer. An siRNA to carrier ratio of 1:24 was determined to be the optimal ratio in the preliminary experiment (Figure 2A). The results showed that, compared with the control, VEGF protein expression was reduced to $32.5 \% \pm 5.2 \%, 41.3 \% \pm$ $6.5 \%, 21.4 \% \pm 8.3 \%$, and $7.8 \% \pm 5.8 \%$ for cells transfected with siPORT NeoFX, HiPerFect, siRNA/HP- $\beta$-CD-PEI, and siRNA/FA-HP- $\beta$-CD-PEI, respectively (Figure 7 ). The highest gene silencing efficiency was achieved using the siRNA/ FA-HP- $\beta$-CD-PEI complexes, and including $20 \%$ calf serum in these complexes provided a strong foundation for their application in vivo.

\section{Selective tumor targeting in vivo}

On the basis of our in vitro gene silencing results, we used the siRNA/FA-HP- $\beta$-CD-PEI complexes to treat tumors. VEGF is known to be involved in angiogenesis, which is a critical factor contributing to tumor growth. Expression of VEGF has been reported to be very high in tumors, and VEGF protein content is closely correlated with tumor growth. ${ }^{36}$

Accordingly, we used siVEGF/FA-HP- $\beta$-CD-PEI complexes to target tumor cells selectively by inhibiting VEGF production. HeLa cells at a population of $1 \times 10^{6}$ were inoculated into nude mice for the preparation of tumor models. After 10 days, the average size of the tumors increased to approximately $80 \mathrm{~mm}^{2}$, after which siVEGF/FA-HP- $\beta$-CDPEI complexes was injected through the tail vein daily for three days. PBS nonspecific siLuc/FA-HP- $\beta$-CD-PEI complexes, and siVEGF/HP- $\beta$-CD-PEI complexes were injected in the same manner as for the controls. By three weeks after the initial injections, all animals in the control group and nonspecific siLuc/FA-HP- $\beta$-CD-PEI group had died as a

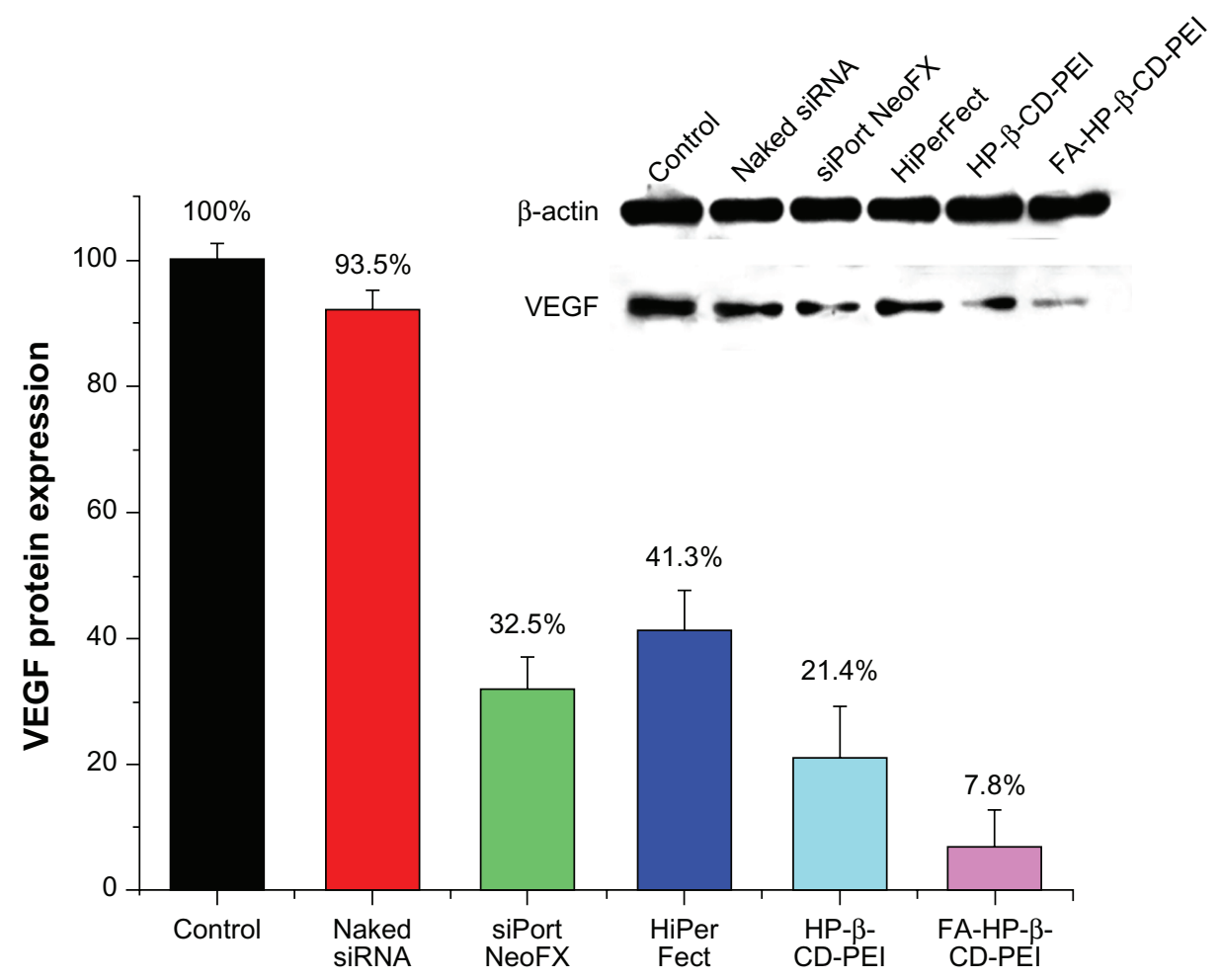

Figure 7 Comparison of gene silencing efficiencies between HP- $\beta-C D-P E I / s i R N A$ and FA-HP- $\beta-C D-P E I / s i R N A$ complexes and commercial transfection reagents by Western blotting in HeLa cells. The level of VEGF protein expression was reduced to $32.5 \pm 5.2 \%, 41.3 \pm 6.5 \%, 21.4 \pm 8.3 \%$ and $7.8 \pm 5.8 \%$ with siPort NeoFX, HiPerFect, siRNA/ HP- $\beta$-CD-PEI and siRNA/FA-HP- $\beta$-CD-PEI; respectively.

Notes: The concentration of siRNA was $100 \mathrm{~nm}$ and the treatment duration was 72 hours. The experiment was performed in culture medium containing $20 \%$ calf serum, which resulted in effective gene silencing by the FA-HP- $\beta$-CD-PEl/siRNA complexes.

Abbreviations: FA, folic acid; HP- $\beta$-CD, 2-hydroxypopyl- $\beta$-cyclodextrin; PEI, polyethyleneimine; siRNA, small interfering RNA; VEGF, vascular endothelial growth factor. 


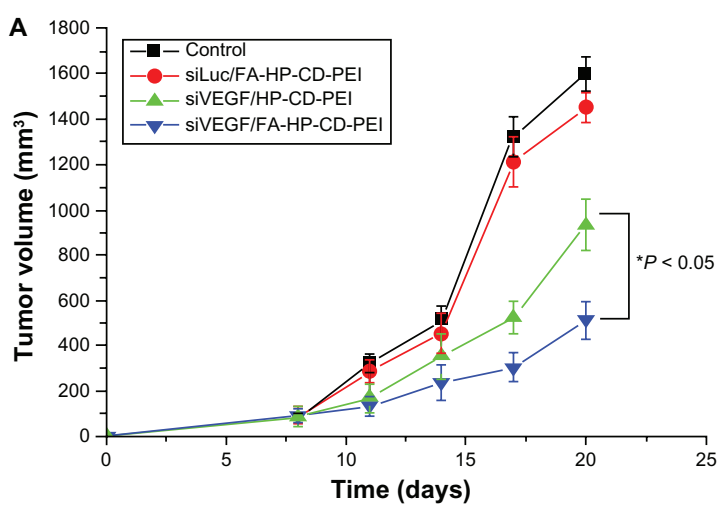

B

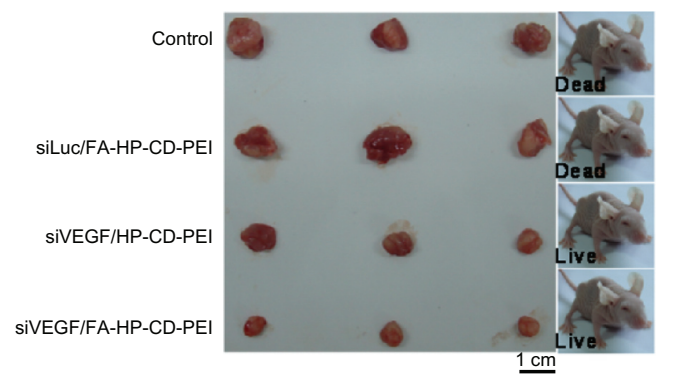

C

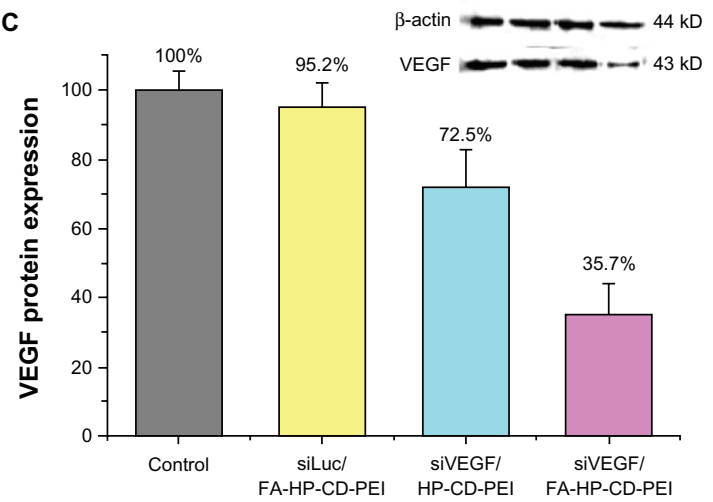

Figure 8 Anti-tumoral therapeutic effect of the VEGF siRNA/FA-HP- $\beta-C D-P E I$ complex in female mice where HeLa cells were injected for tumor inoculation and growth. (A) The change in the tumor volume over time after intra-tumoral injection of a control (PBS solution), siVEGF/HP- $\beta$-CD-PEI, non-specific Luc siRNA (siLuc)/ FA-HP- $\beta$-CD-PEI and siVEGF/FA-HP- $\beta$-CD-PEl complexes. The treatments were performed three times after $8, \mathrm{II}$ and $\mathrm{I} 4$ days $(* P<0.05$ versus the control). The tumor of control group and the siLuc/FA-HP- $\beta$-CD-PEl group grew obviously in 20 days, but the tumor of siVEGF/HP- $\beta$-CD-PEI group and siVEGF/FA-HP- $\beta$-CD-PEI was inhibited obviously, especially the siVEGF/FA-HP- $\beta-C D-P E I$ group, the tumor grew slowly. (B) Photo-images of the dissected tumor tissues after 20 days: showed the condition of tumor growth in 4 different treatment group directly (The tumor of control group and the siLuc/FA-HP- $\beta$-CD-PEl group grew obviously in 20 days, and the growth of tumor in siVEGF/HP- $\beta$-CD-PEI group and siVEGF/FA-HP- $\beta-C D-P E I$ group was inhibited). (C) Comparison of VEGF protein levels in the tumor tissues after 20 days, the expression of VEGF protein was inhibited obviously in siVEGF/ HP- $\beta$-CD-PEl group and siVEGF/FA-HP- $\beta$-CD-PEI group (especially in siVEGF/FAHP- $\beta$-CD-PEl group).

Note: The data were normalized with $\beta$-actin protein levels.

Abbreviations: FA, folic acid; HP- $\beta-C D$, 2-hydroxypopyl- $\beta$-cyclodextrin; PBS, phosphate buffered saline; PEI, polyethyleneimine; VEGF, vascular endothelial growth factor; siVEGF, siRNA against VEGF.

result of excessive tumor burden. Figure $8 \mathrm{~A}$ shows that the siVEGF/FA-HP- $\beta$-CD-PEI complexes suppressed tumor growth to a significantly greater extent than in the other groups $(P<0.05)$. Tumor tissue recovered after 20 days confirmed the gene silencing efficiency of the siVEGF/FA-HP- $\beta$-CD-PEI complexes (Figure 8B).

VEGF protein expression was investigated further to confirm the gene silencing efficiency of the siVEGF/ FA-HP- $\beta$-CD-PEI complexes. This was achieved by sacrificing three mice from each group at 24 hours after the final injection and subjecting the tumor samples to Western blotting. The results demonstrated that the siVEGF/FA-HP- $\beta$ CD-PEI complexes downregulated VEGF protein expression to $35.7 \%$ in comparison with the other control groups (Figure $8 \mathrm{C}$ ). It was further shown that relative VEGF protein expression in tumor tissues decreased to $72.5 \%$, which was statistically significant. The siVEGF/HP- $\beta$-CD-PEI complex was also somewhat effective for inhibition of tumor growth, as shown in Figure 8B and C, and there are probably several reasons for this observation. The FA cross-linked to the carrier complex enabled the nanoparticle to target the tumor, and was adsorbed onto the tumor surface by the FA receptor. The VEGF siRNA was delivered into the cancer cells by cellular uptake; ${ }^{19,33}$ and HP- $\beta$-CD increased the biocompatibility of the nanoparticle and also the cycle time in blood to make more nanoparticles adsorb onto the tumor surface. ${ }^{20}$ Finally, knock-down of VEGF expression in the tumor cells inhibited tumor growth. ${ }^{26,34}$

Considering these results, we conclude that the FA-HP$\beta$-CD-PEI carrier conjugate efficiently delivered siRNA to target tissues containing the FA receptor. This contributed to $V E G F$ gene silencing, which in turn translated into therapeutic effects in tumor tissue. The siVEGF/FA-HP$\beta$-CD-PEI complex could be potentially developed as an antiangiogenic agent for the treatment of a range of diseases involving the FA receptor.

\section{Conclusion}

Development of a target-specific FA-HP- $\beta-C D-P E I$ carrier as a delivery system for siRNA therapeutics was successfully achieved in the present study. This siRNA delivery system showed no toxicity either in vitro or in vivo, and had high siRNA transfection efficiency. In addition, superior gene silencing efficiency (of more than 90\%) was achieved in vitro. The FA included on the surface of the siRNA/FA-HP- $\beta$-CD-PEI complex contributed to effective cellular uptake via FA receptor-mediated endocytosis. Gene silencing efficiency was improved in the presence of serum because of avoidance of nonspecific binding with serum proteins. Subsequent in vivo experiments demonstrated that the siRNA/FA-HP- $\beta$-CD-PEI complexes were delivered successfully to selectively targeted tumors by VEGF siRNA that led to inhibition of tumor growth. 
Our findings confirm the ability to target tumors selectively using novel polymers for siRNA delivery. Examples of new roles for these polymers could include polycations with favorable characteristics such as nucleic acid binding, compaction, protection, biocompatibility, lack of cytotoxicity, and targeted delivery. This work provides a useful framework for guiding targeted siRNA delivery in vivo in order to achieve efficient gene silencing as part of cancer therapy in the future.

\section{Acknowledgments}

This work was financially supported by grants from the National Natural Science Foundation of China (20831006, 21121061, 21231007), the Guangdong Provincial Natural Science Foundation (9351027501000003), the Ministry of Education of China (20100171110013, 313058), and the Fundamental Research Funds for the Central Universities. The National High-Tech Research and Development Programme of China (863 Program, 2012AA020305).

\section{Disclosure}

The authors report no conflicts of interest in this work.

\section{References}

1. Fire A, Xu S, Montgomery MK, Kostas SA, Driver SE, Mello CC. Potent and specific genetic interference by double-stranded RNA in Caenorhabditis elegans. Nature. 1998;391:806-811.

2. Kim DH, Rossi JJ. Strategies for silencing human disease using RNA interference. Nat Rev Genet. 2007;8:173-184.

3. Whitehead KA, Langer R, Anderson DG. Knocking down barriers: advances in siRNA delivery. Nat Rev Drug Discov. 2009;8:129-138.

4. Miele E, Spinelli GP, Miele E, et al. Nanoparticle-based delivery of small interfering RNA: challenges for cancer therapy. Int $J$ Nanomedicine. 2012;7:3637-3657.

5. Mintzer MA, Simanek EE. Nonviral vectors for gene delivery. Chem Rev. 2009;109:259-302.

6. Shen M, Gong F, Pang P, et al. An MRI-visible non-viral vector for targeted Bcl-2 siRNA delivery to neuroblastoma. Int J Nanomedicine. 2012;7:3319-3332.

7. Yao YD, Sun TM, Huang SY, et al. Targeted delivery of PLK1-siRNA by $\mathrm{ScFv}$ suppresses Her2+ breast cancer growth and metastasis. Sci Transl Med. 2012;4:130-148.

8. Alameh M, Dejesus D, Jean M, et al. Low molecular weight chitosan nanoparticulate system at low N:P ratio for nontoxic polynucleotide delivery. Int J Nanomedicine. 2012;7:1399-1414.

9. Zhou J, Rossi JJ. Therapeutic potential of aptamer-siRNA conjugates for treatment of HIV-1. BioDrugs. 2012;26:393-400.

10. Kummitha CM, Malamas AS, Lu ZR. Albumin pre-coating enhances intracellular siRNA delivery of multifunctional amphiphile/siRNA nanoparticles. Int J Nanomedicine. 2012;7:5205-5214.

11. Li JM, Zhao MX, Su H, et al. Multifunctional quantum-dot-based siRNA delivery for HPV18 E6 gene silence and intracellular imaging. Biomaterials. 2011;32:7978-7987.

12. Gao K, Huang L. Nonviral methods for siRNA delivery. Mol Pharm. 2009;6:651-658.

13. de Fougerolles AR. Delivery vehicles for small interfering RNA in vivo. Hum Gene Ther. 2008;19:125-132.
14. Lv H, Zhang S, Wang B, Cui S, Yan J. Toxicity of cationic lipids and cationic polymers in gene delivery. J Control Release. 2006;114:100-109.

15. Boussif O, Lezoualc'h F, Zanta MA, et al. A versatile vector for gene and oligonucleotide transfer into cells in culture and in vivo: polyethylenimine. Proc Natl Acad Sci U S A. 1995;92:7297-7301.

16. Gary DJ, Puri N, Won YY. Polymer-based siRNA delivery: perspectives on the fundamental and phenomenological distinctions from polymer-based DNA delivery. J Control Release. 2007;121:64-73.

17. Godbey WT, Wu KK, Mikos AG. Poly(ethylenimine) and its role in gene delivery. J Control Release. 1999;60:149-160.

18. Fischer D, Li YX, Ahlemeyer B, Krieglstein J, Kissel T. In vitro cytotoxicity testing of polycations: influence of polymer structure on cell viability and hemolysis. Biomaterials. 2003;24:1121-1131.

19. Yao H, Ng SS, Tucker WO, et al. The gene transfection efficiency of a folate-PEI600-cyclodextrin nanopolymer. Biomaterials. 2009;30: 5793-5803.

20. Li J, Loh XJ. Cyclodextrin-based supramolecular architectures: synthesis, structures, and applications for drug and gene delivery. Adv Drug Deliv Rev. 2008;60:1000-1017.

21. Davis ME, Brewster ME. Cyclodextrin-based pharmaceutics: past, present and future. Nat Rev Drug Discov. 2004;3:1023-1035.

22. Cryan SA, Holohan A, Donohue R, Darcy R, O'Driscoll CM. Cell transfection with polycationic cyclodextrin vectors. Eur J Pharm Sci. 2004;21:625-633

23. Pun SH, Bellocq NC, Liu AJ, et al. Cyclodextrin-modified polyethylenimine polymers for gene delivery. Bioconjug Chem. 2004;15: 831-840.

24. Hu QD, Fan H, Lou WJ, Wang QQ, Tang GP. Polyethyleniminecyclodextrin-tegafur conjugate shows anti-cancer activity and a potential for gene delivery. J Zhejiang Univ Sci B. 2011;12:720-729.

25. Forrest ML, Gabrielson N, Pack DW. Cyclodextrin-polyethylenimine conjugates for targeted in vitro gene delivery. Biotechnol Bioeng. 2005; $89: 416-423$

26. Liang B, He M, Chan $\mathrm{C}$, et al. The use of folate-PEG-graftedhybranched-PEI nonviral vector for the inhibition of glioma growth in the rat. Biomaterials. 2009;30:4014-4020.

27. Huang HL, Yu H, Tang GP, Wang QQ, Li J. Low molecular weight polyethylenimine cross-linked by 2-hydroxypropyl-r-cyclodextrin coupled to peptide targeting HER2 as a gene delivery vector. Biomaterials. 2010;31:1830-1838.

28. Park K, Lee MY, Kimb KS, Hahn SK. Target specific tumor treatment by VEGF siRNA complexed with reducible polyethyleneimine hyaluronic acid conjugate. Biomaterials. 2010;31:5258-5265.

29. Peer D, Karp JM, Hong S, Farokhzad OC, Margalit R, Langer R. Nanocarriers as an emerging platform for cancer therapy. Nat Nanotechnol. 2007;2:751-760.

30. Huang HL, Tang GP, Wang QQ, et al. Two novel non-viral gene delivery vectors: low molecular weight polyethylenimine cross-linked by (2-hydroxypropyl)- $\beta$-cyclodextrin or (2-hydroxypropyl)-c-cyclodextrin. Chem Commun. 2006;22:2382-2384.

31. Ogris M, Steinlein P, Kursa M, Mechtler K, Kircheis R, Wagner E. The size of DNA/transferrin-PEI complexes is an important factor for gene expression in cultured cells. Gene Ther. 1998;5:1425-1433.

32. Chollet P, Favrot MC, Hurbin A, Coll JL. Side-effects of a systemic injection of linear polyethylenimine-DNA complexes. J Gene Med. 2002;4:84-91.

33. Hwang SJ, Bellocq NC, Davis ME. Effects of structure of $\beta$-cyclodextrin-containing polymers on gene delivery. Bioconjug Chem. 2001;12:280-290.

34. Arote R, Hwang SK, Lim HT, et al. The therapeutic efficiency of FPPEA/TAM67 gene complexes via folate receptor-mediated endocytosis in a xenograft mice model. Biomaterials. 2010;31:2435-2445.

35. Sudimach BA, Lee RJ. Targeted drug delivery via the folate receptor. Adv Drug Deliv Rev. 2000;41:147-162.

36. Ellis LM, Hicklin DJ. VEGF-targeted therapy: mechanisms of antitumor activity. Nat Rev Cancer. 2008;8:579-591. 


\section{Supplementary materials}

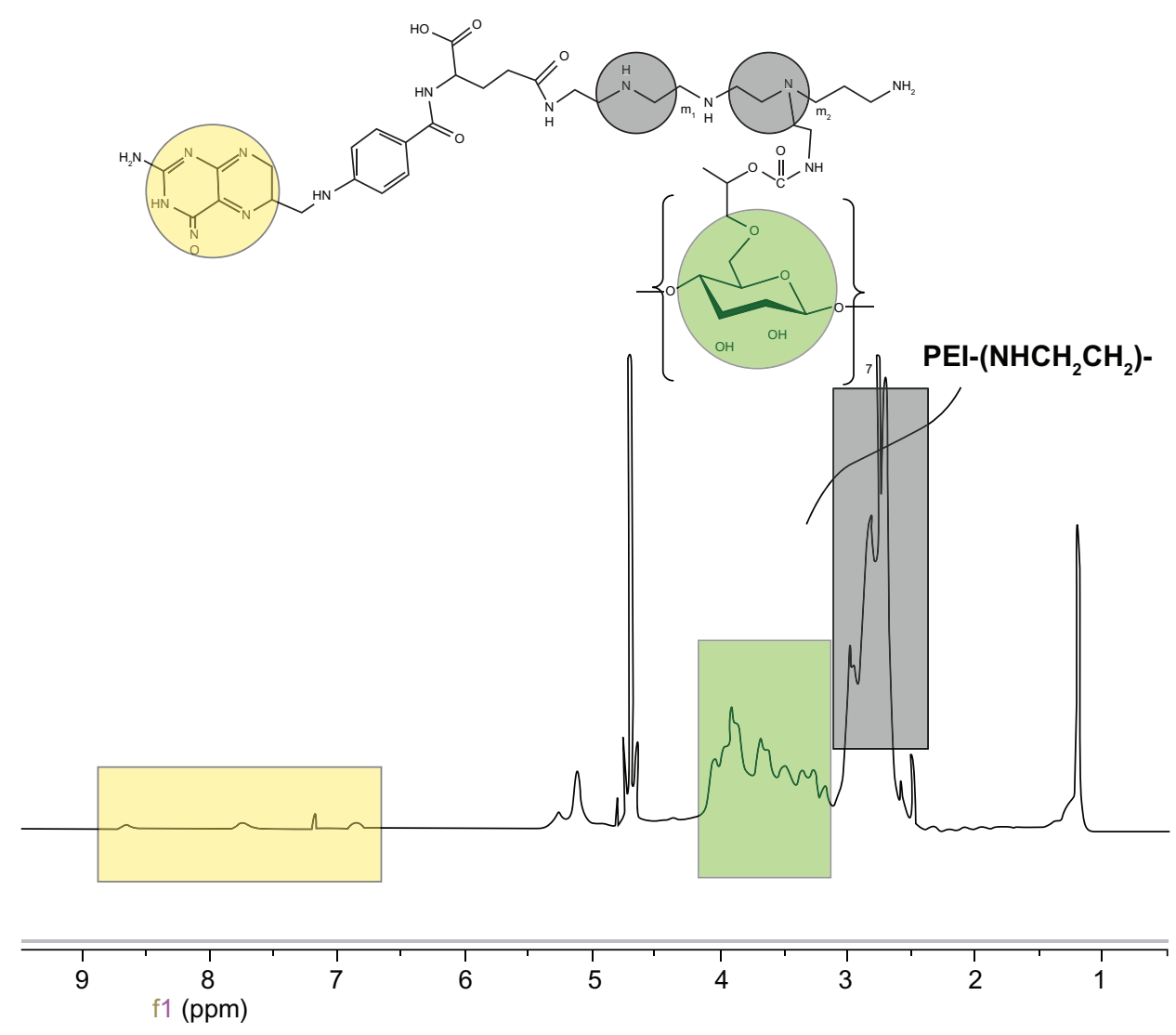

Figure SI 'H nuclear magnetic resonance spectra for the reducible FA-HP- $\beta$-CD-PEl conjugate. The ratio of cyclodextrin to PEl in the new polymers was calculated based on the proton integral values of the ' $\mathrm{H}$ nuclear magnetic resonance spectrum (Varian $400 \mathrm{mHz}, \mathrm{D} 2 \mathrm{O})$ showing $1.038 \mathrm{ppm}\left(\mathrm{CH}_{3}\right.$ of hydroxypropyl) and 2.4-3.0 ppm $\left(\mathrm{CH}_{2}\right.$ of PEI).

Notes: This ratio was found to be 1:3.I for cyclodextrin and PEI $600 \mathrm{Da}$ (mole to mole). The area of 6.5-8.5 ppm was the benzene ring in the characteristic peak of FA, which was weakening, confirming the linkage between FA and HP- $\beta-C D-P E I$.

Abbreviations: FA, folic acid; HP- $\beta-C D$, 2-hydroxypopyl- $\beta$-cyclodextrin; PEI, polyethyleneimine. 

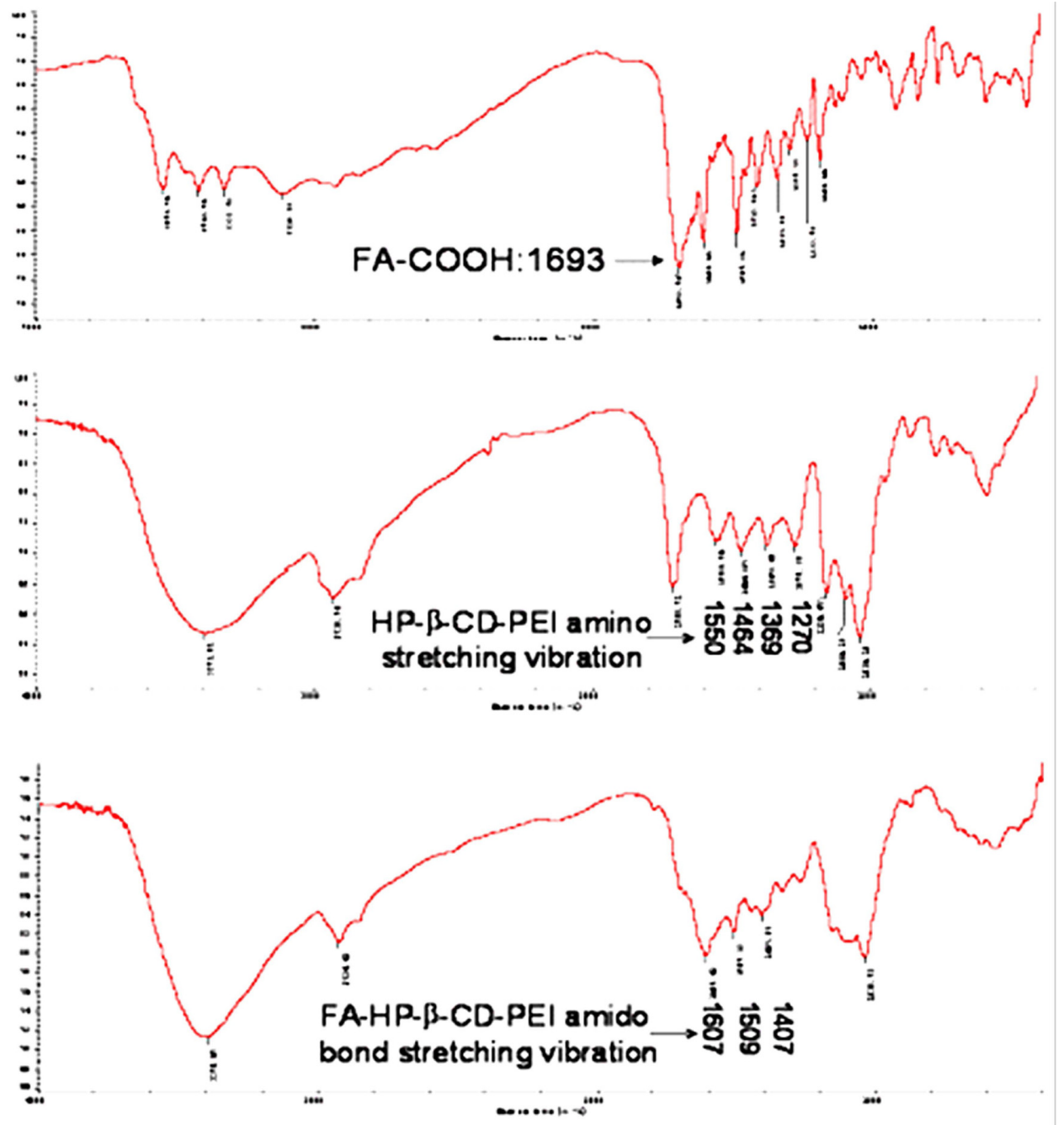

Figure S2 Fourier transform infrared spectroscopy of the reducible FA-HP- $\beta$-CD-PEl conjugate. On analysis, the yellow water-soluble solid product deemed to be FAHP- $\beta$-CD-PEI-600 has the characteristic -CO-NH- peak of I607, 1509, and I407 which is different from the carboxyl of FA (characteristic peak 1693) and the amino of HP- $\beta$-CD-PEI-600 (characteristic peaks I550, 1464, 1369, and I270). This further confirms the linkage between FA and HP- $\beta$-CD-PEI.

Abbreviations: FA, folic acid; HP- $\beta$-CD, 2-hydroxypopyl- $\beta$-cyclodextrin; PEl, polyethyleneimine.

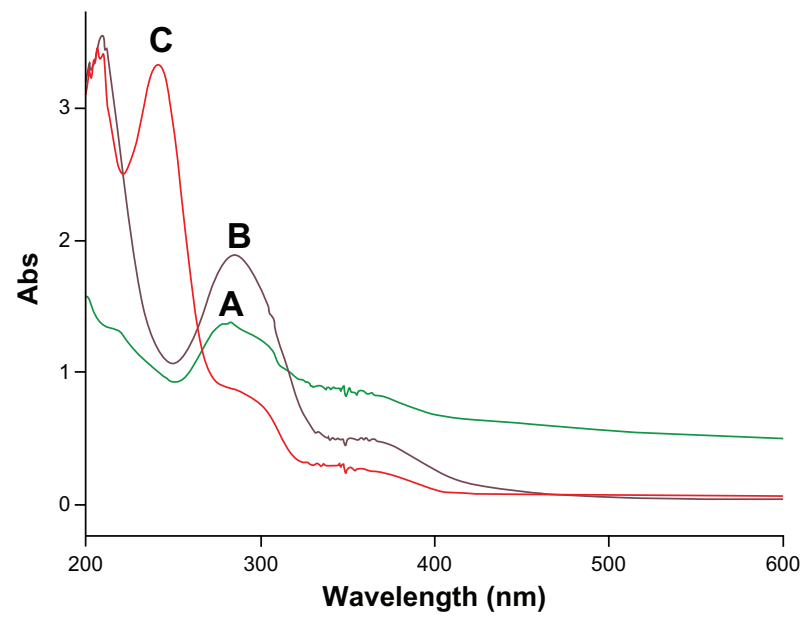

Figure S3 Ultraviolet-visible spectra of (A) FA, (B) FA-HP- $\beta-C D-P E I-600$, and (C) HP- $\beta-C D-P E I-600$. (A) and (B) have the absorption peak of FA and (C) does not. Abbreviations: FA, folic acid; HP- $\beta-C D$, 2-hydroxypopyl- $\beta$-cyclodextrin; PEl, polyethyleneimine. 


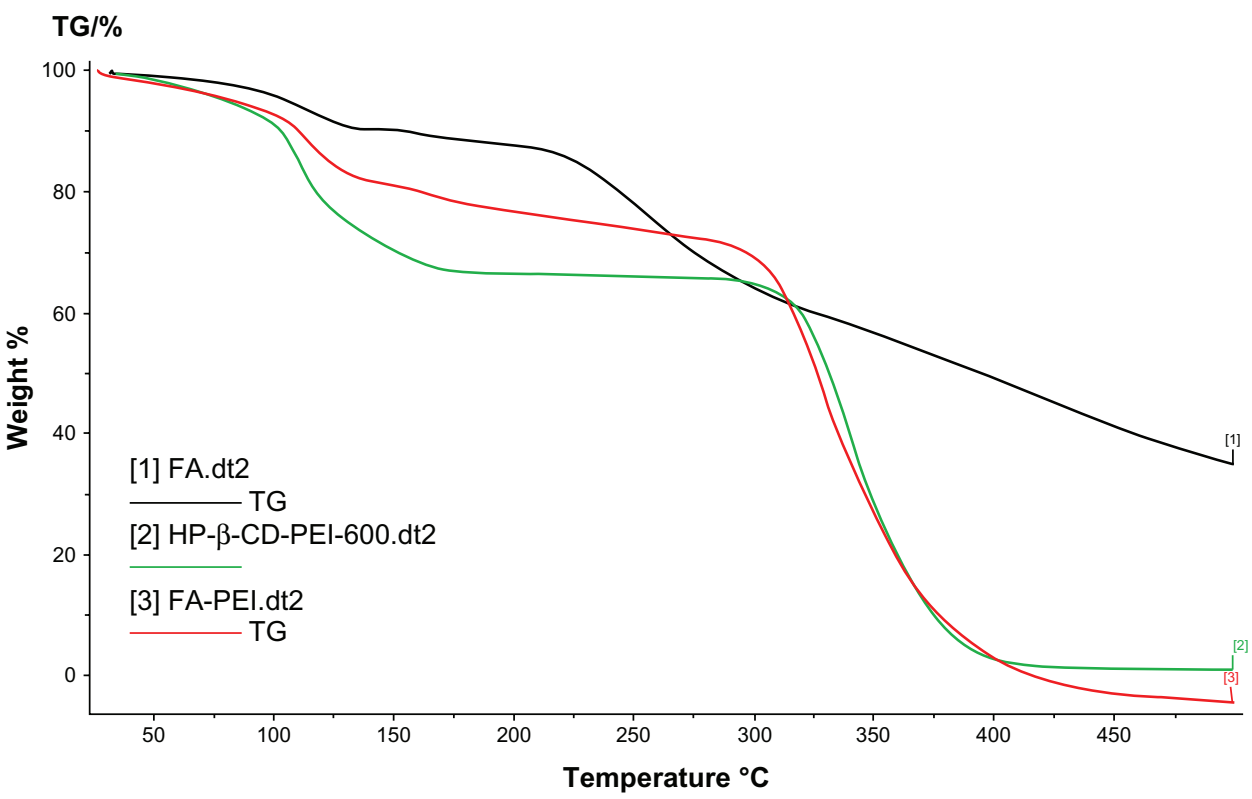

Figure S4 Thermogravimetric analysis of (I) FA, (2) HP- $\beta-C D-P E I-600$, and (3) FA-HP- $\beta-C D-P E I-600$.

Note: The thermogravimetric results for FA-HP- $\beta-C D-P E I-600$ show two degradation temperatures indicating that this compound has two components, in contrast with FA and HP- $\beta$-CD-PEI-600 which have only one component.

Abbreviations: FA, folic acid; HP- $\beta-C D$, 2-hydroxypopyl- $\beta$-cyclodextrin; PEI, polyethyleneimine.

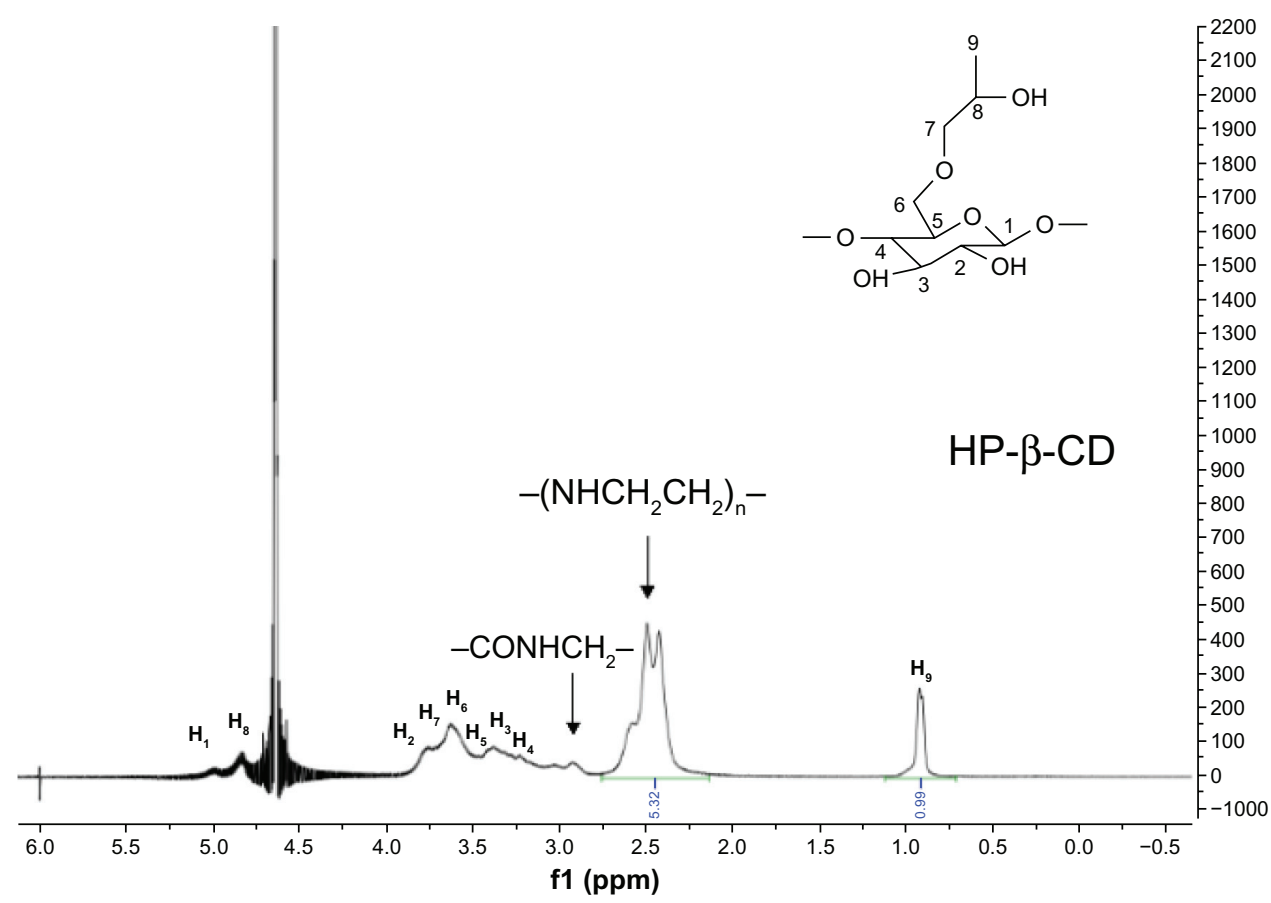

Figure S5 'H nuclear magnetic resonance analysis of HP- $\beta$-CD-PEI.

Abbreviations: HP- $\beta-C D$, 2-hydroxypopyl- $\beta$-cyclodextrin; $\mathrm{PEI}$, polyethyleneimine. 
A

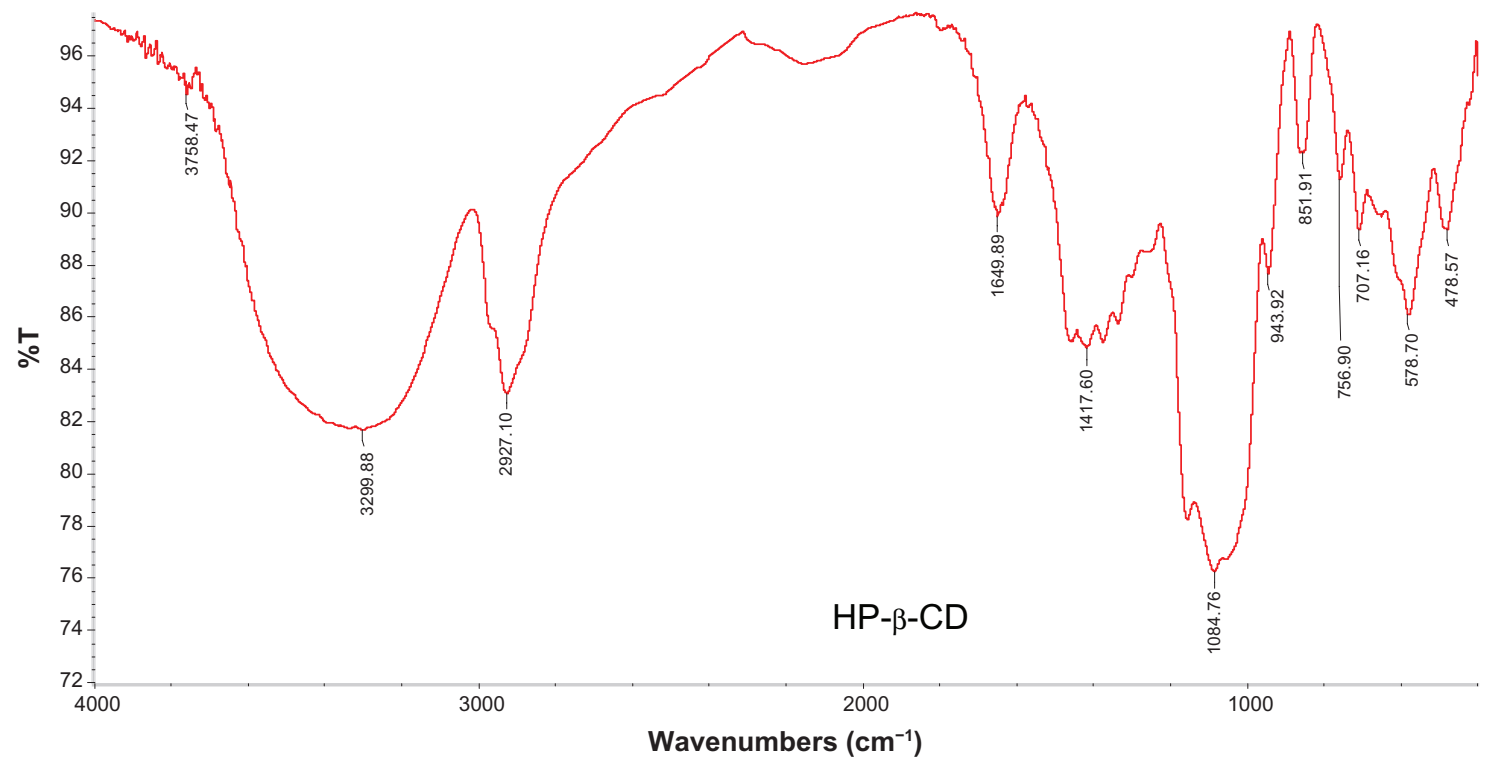

B

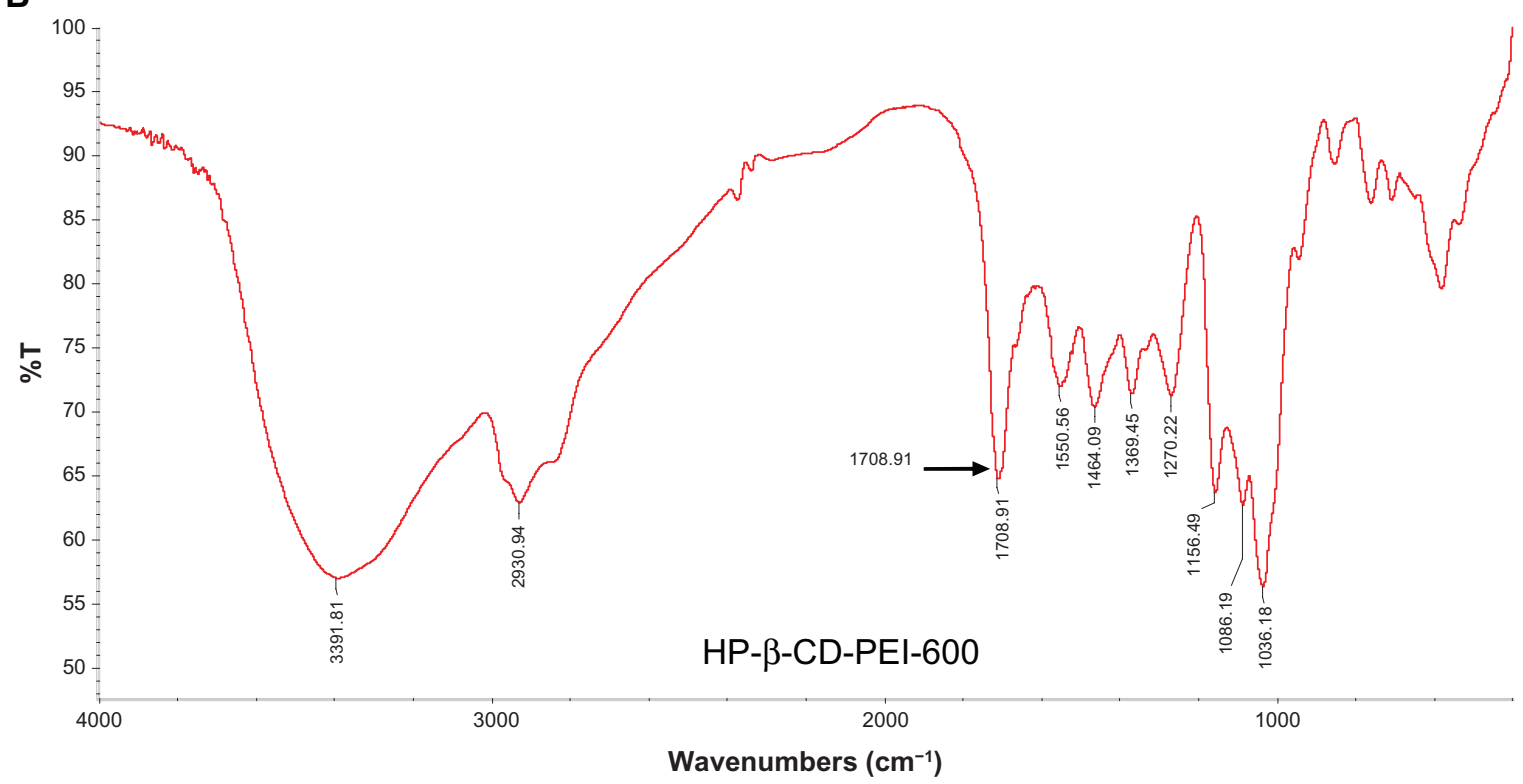

Figure S6 Fourier transform infrared analysis of HP- $\beta$-CD-PEl. (A) HP- $\beta-C D$ and (B) HP- $\beta-C D-P E I$.

Note: Compared with HP- $\beta$-CD, HP- $\beta$-CD-PEl contains a new absorption peak for a carbonyl group appearing at 1708.91 .

Abbreviations: FA, folic acid; HP- $\beta-C D$, 2-hydroxypopyl- $\beta$-cyclodextrin; PEI, polyethyleneimine.

Table SI Characteristics of the HP- $\beta-C D-P E I$ and FA-HP- $\beta-C D-P E I$ used in this study ( $\mathrm{pH} 7.4$, room temperature)

\begin{tabular}{|c|c|c|c|c|c|}
\hline & Mn & Mw & Polydispersity & Size $(\mathrm{nm})$ & Zeta potential $(\mathrm{mV})$ \\
\hline HP- $\beta-C D-P E I$ & 9982 & 11675 & I.169605 & $305.6 \pm 2.4$ & $36.4 \pm 1.5$ \\
\hline FA-HP- $\beta-C D-P E I$ & 14422 & 14565 & 1.009547 & $344.2 \pm 3.7$ & $30.6 \pm 2.8$ \\
\hline HP- $\beta-C D-P E I / s i R N A$ & - & - & - & $264.5 \pm 5.3$ & $25.5 \pm 2.3$ \\
\hline FA-HP- $\beta-C D-P E I / s i R N A$ & - & - & - & $302.3 \pm 1.7$ & $22.4 \pm 4.2$ \\
\hline
\end{tabular}

Abbreviations: Mn, molecular number; Mw, molecular weight; FA, folic acid; HP- $\beta$-CD, 2-hydroxypopyl- $\beta$-cyclodextrin; PEl, polyethyleneimine; siRNA, small interfering RNA. 


\section{Methods used to calculate amine content of FA-HP- $\beta-C D-P E I$ and N/P ratio}

The molecular weight of PEI used was $600 \mathrm{Da}$, with an amine content of $20 \mathrm{mmol} / \mathrm{g}$, a primary amine content of $35 \%$, a secondary amine content of $35 \%$, and a tertiary amine content of $30 \%$. Therefore, the amount of nitrogen in HP- $\beta$-CD-PEI and FA-HP- $\beta$-CD-PEI could be calculated. The siRNA used had 21 nucleotide base pairs. The N/P ratio is the amount of nitrogen in FA-HP- $\beta$-CD-PEI/amount of phosphorus in siRNA. In the N/P ratio experiment, the molar mass of FA-HP- $\beta$-CD-PEI was gradually increased and the molar mass of siRNA was constant. The N/P ratio showed a gradual increment (ie, 0, 1.2, 2.4, 6, 12, and 24).

Abbreviations: FA, folic acid; HP- $\beta-\mathrm{CD}$, 2-hydroxypopyl$\beta$-cyclodextrin; PEI, polyethyleneimine; VEGF, vascular endothelial growth factor; siVEGF, siRNA against VEGF.

\section{Publish your work in this journal}

The International Journal of Nanomedicine is an international, peerreviewed journal focusing on the application of nanotechnology in diagnostics, therapeutics, and drug delivery systems throughou the biomedical field. This journal is indexed on PubMed Central, MedLine, CAS, SciSearch $®$, Current Contents ${ } /$ Clinical Medicine,
Journal Citation Reports/Science Edition, EMBase, Scopus and the Elsevier Bibliographic databases. The manuscript management system is completely online and includes a very quick and fair peer-review system, which is all easy to use. Visit http://www.dovepress.com/ testimonials.php to read real quotes from published authors. 